
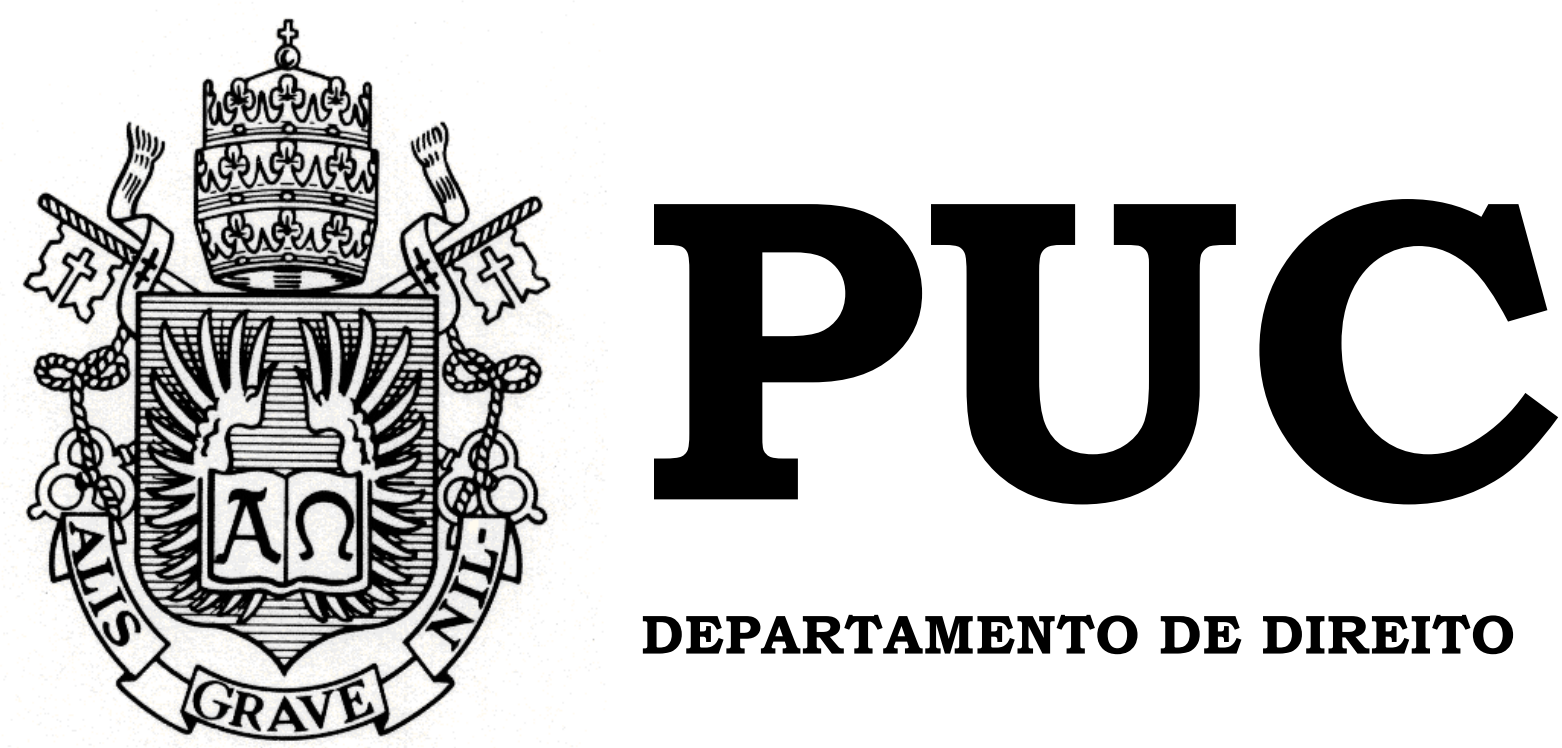

DEPARTAMENTO DE DIREITO

\title{
O PROJETO SOBRE RECONHECIMENTO E EXECUÇÃO DE SENTENÇAS DA CONFERÊNCIA DA HAIA
}

por

JULIA DE PAIVA POTSCH

ORIENTADORA: Nadia de Araujo

2017.1

PONTIFÍCIA UNIVERSIDADE CATÓLICA DO RIO DE JANEIRO RUA MARQUÊS DE SÃO VICENTE, 225 - CEP 22453-900RIO DE JANEIRO - BRASIL 


\title{
O PROJETO SOBRE RECONHECIMENTO E EXECUÇÃO DE SENTENÇAS DA CONFERÊNCIA DA HAIA
}

\author{
por
}

\section{JULIA DE PAIVA POTSCH}

\begin{abstract}
Monografia apresentada ao Departamento de Direito da Pontificia Universidade Católica do Rio de Janeiro (PUC-Rio) para a obtenção do Título de Bacharel em Direito.
\end{abstract}

Orientadora: Nadia de Araujo 


\section{Dedicatória}

Aos meus pais, meu namorado e meus amigos, por todo o apoio e incentivo e por sempre acreditarem na minha capacidade. 


\section{Agradecimentos}

Aos meus pais, por me proporcionarem tantas oportunidades, me apoiarem em todos os aspectos da minha vida e me amarem incondicionalmente.

Ao meu namorado, que me ajuda a ser uma pessoa cada vez melhor e sempre me lembra que "vai dar tudo certo".

Às minhas amigas do colégio, minhas irmãs do coração, que já passaram por tantas fases da vida comigo e me mostraram que às vezes é preciso levar a vida menos a sério.

Aos meus amigos da PUC, que me acompanharam nesses cinco anos cheios de emoções e fizeram essa fase da vida ser tão incrível e inesquecível.

À minha orientadora, Nadia de Araujo, por todas as orientações e ensinamentos, e por compartilhar seus conhecimentos com paciência e dedicação.

A todos os meus professores, do colégio até a faculdade. Vocês foram essenciais na minha formação como pessoa e eu não poderia ser mais grata.

Finalmente, à Pontifícia Universidade Católica do Rio de Janeiro, por ter me proporcionado cinco anos de muitos aprendizados, superações e experiências que vou levar para o resto da vida. 


\section{Resumo}

A Conferência da Haia de Direito Internacional Privado se dedica à elaboração de normas que buscam promover uma harmonização e uniformização desta área do direito, possibilitando relações e transações mais facilitadas entre diferentes Estados, com diminuição de custos, maior segurança jurídica e um acesso à justiça mais eficaz. O Projeto sobre Reconhecimento e Execução de Sentenças (Judgments Project) da Conferência da Haia tem o objetivo de estabelecer um sistema mais simplificado de circulação internacional de sentenças, que assegure a segurança jurídica e a eficácia necessárias para a viabilização de uma verdadeira cooperação jurídica internacional. O presente trabalho se dispõe a analisar este Projeto, os impactos que a futura Convenção, resultado do Projeto, pode causar no Brasil e os dispositivos legais do ordenamento jurídico brasileiro (em especial, do $\mathrm{CPC} / 2015$ ) que têm relação com a jurisdição internacional e a homologação de sentenças estrangeiras.

\section{Palavras-chave:}

Direito Internacional Privado; Conferência da Haia de Direito Internacional Privado; Judgments Project; convenção internacional; reconhecimento e execução de sentenças estrangeiras; bases indiretas de jurisdição; cooperação jurídica internacional; eleição de foro; CPC/2015; jurisdição internacional. 


\section{Sumário}

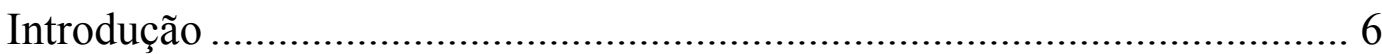

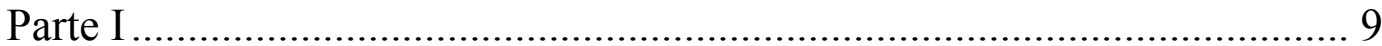

1. Jurisdição internacional no Código de Processo Civil de 2015 ................. 9

2. O Projeto sobre Reconhecimento e Execução de Sentenças

Estrangeiras: Judgments Project ............................................................... 27

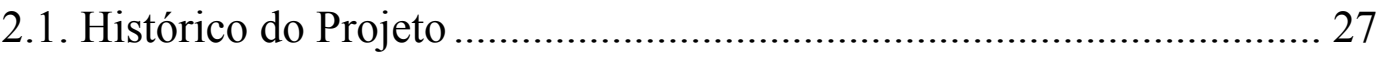

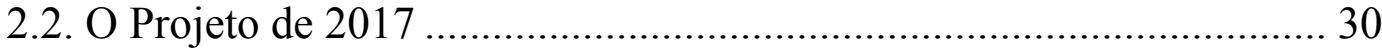

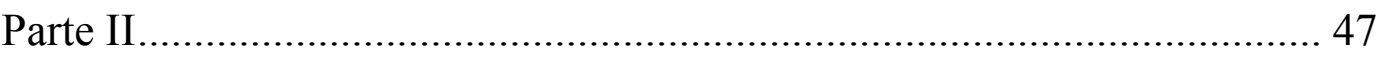

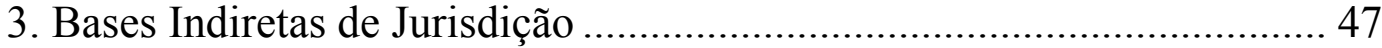

4. Impactos da Convenção no Brasil............................................................ 58

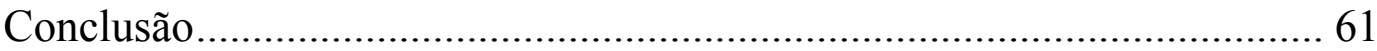

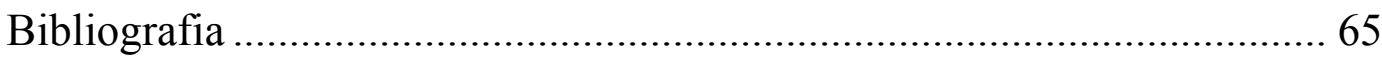

Anexo: Projeto da Convenção (February 2017 Draft Convention)..............71 


\section{Introdução}

A Conferência da Haia de Direito Internacional Privado (“Conferência da Haia") é uma organização intergovernamental, que busca o desenvolvimento de instrumentos jurídicos multilaterais que possibilitem e facilitem as relações entre pessoas físicas e jurídicas de diferentes Estados. Em 1983 foi realizada sua primeira reunião e, com a entrada em vigor de seu Estatuto em 1955, a organização adquiriu seu caráter permanente. O propósito da Conferência da Haia, como estabelece o artigo $1^{\mathrm{o}}$ de seu Estatuto, é "trabalhar para a unificação progressiva das normas de direito internacional privado"

Contando atualmente com a participação de 81 Estados membros (e um número ainda maior de Estados participantes), de todos os continentes, a Conferência da Haia trabalha continuamente na busca por uma harmonização e uniformização do direito internacional privado, especialmente em questões relativas à competência internacional de tribunais, ao direito aplicável, à proteção de crianças e jovens, ao direito matrimonial e ao estatuto pessoal, além do reconhecimento e execução de sentenças $^{2}$. Este último ponto é o tema central de um dos projetos mais importantes ainda em andamento na Conferência da Haia, o Judgments Project, conhecido no Brasil como Projeto sobre Reconhecimento e Execução de Sentenças Estrangeiras (ou apenas Projeto Sentenças).

A ideia do Judgments Project é que sejam reduzidos os riscos e custos encontrados em relações e transações entre pessoas físicas e jurídicas de diferentes Estados, que muitas vezes possuem sistemas jurídicos distintos e, desta forma, a futura Convenção resultado do Projeto facilitaria o comércio e os investimentos transfronteiriços, garantindo não apenas a segurança jurídica necessária para que as partes se sintam confiantes ao

\footnotetext{
${ }^{1} \mathrm{O}$ Estatuto da Conferência da Haia de Direito Internacional Privado está disponível em: $<$ https://www.hcch.net/pt/instruments/conventions/full-text> Acesso em: 05 mar. 2017.

${ }^{2}$ Informações sobre a Conferência da Haia disponíveis em: < https://www.hcch.net/pt/about/>. Acesso em: 05 mar. 2017.
} 
engajar em tais relacionamentos, como também um amplo acesso à justiça ${ }^{3}$. Na prática, isso será alcançado com uma Convenção que estabeleça regras a serem observadas pelos Estados Contratantes quando se depararem com uma sentença estrangeira que precisa ser reconhecida ou executada. Assim, com esse núcleo de regras e preceitos dispostos na Convenção e amplamente aceitos pelos países, as sentenças poderão circular entre os Estados e atingir sua pretendida eficácia. As pessoas não procuram os tribunais apenas para receberem um pedaço de papel; é preciso que a decisão ali contida possa ser cumprida de forma concreta, como aponta o Presidente (Chair) da Comissão Especial responsável por preparar a Convenção:

Access to justice means access to practical justice; just outcomes that are given effect. In today's increasingly globalised world, it is ever more necessary for that practical effect to span borders, if justice is to be effective. So, the goal of access to justice, access to practical just outcomes wherever they need to be found, is at the heart of our work. ${ }^{4}$

Através dessa base legal utilizada por todos os Estados Contratantes, que garante a eficácia das decisões e evita a litispendência internacional, os processos se tornam mais eficientes e são reduzidas as despesas judiciais. Como resultado, a circulação de decisões no plano internacional se torna naturalmente menos complexa e mais almejada, por possibilitar que transações e negócios transfronteiriços sejam realizados com maior facilidade ${ }^{5}$.

\footnotetext{
${ }^{3}$ Record of Introductory Remarks of the Chair of the Special Commission (1-9 June 2016). Haia: Conferência da Haia de Direito Internacional Privado, 2017. p. 2.

${ }^{4}$ Ibid. p. 2.

Tradução livre da autora: Acesso à justiça significa acesso à justiça prática; resultados justos que produzam efeitos. No mundo cada vez mais globalizado de hoje, é cada vez mais necessário que efeitos práticos abranjam fronteiras, para que a justiça seja efetiva. Assim, o objetivo do acesso à justiça, acesso à resultados justos e práticos onde quer que eles precisem ser encontrados, está no coração do nosso trabalho.

${ }^{5}$ POTSCH, Julia; DAPIEVE, Marianna; ALMEIDA, Renato de. Cooperação Jurídica Internacional: o Projeto sobre Reconhecimento e Execução de Sentenças da Conferência da Haia de Direito Internacional Privado. Rio de Janeiro. 2016. 20p. Pibic - Departamento de Direito da PUC-Rio.
} 
O presente trabalho, cujo objetivo é analisar o Judgments Project e sua relevância não apenas no âmbito internacional, mas também especificamente para o Brasil, foi organizado de forma que os temas sejam apresentados em duas partes.

Na primeira parte, aborda-se primeiramente o Código de Processo Civil de 2015 e suas normas referentes à jurisdição internacional e à cooperação jurídica internacional, apontando-se os avanços deste Código nessa área, quando comparado ao Código de Processo Civil de 1973. É apresentado o histórico do Projeto, ou seja, como surgiu a ideia para sua criação e o que ocorreu desde então até o momento atual, ressaltando sua importância no cenário mundial; também é brevemente discutida a Convenção sobre os Acordos de Eleição de Foro de 2005. Finalmente, ainda na primeira parte do trabalho, se expõe o Projeto em si, com enfoque nas negociações da última reunião realizada em Haia, em fevereiro de 2017, e nas discussões sobre assuntos que ainda não estão pacificados e que geraram ou ainda podem gerar controvérsias.

A segunda parte desta monografia se dedica às bases indiretas de jurisdição, com uma análise das hipóteses previstas pelo artigo que trata desse ponto tão fundamental do Projeto, finalizando com um exame dos possíveis impactos da futura Convenção com relação ao Brasil. 


\section{Jurisdição internacional no Código de Processo Civil de} 2015

O Código de Processo Civil de 2015 (“CPC/2015”) trouxe inovações relativas à jurisdição internacional e à cooperação jurídica internacional. Seus artigos 21 a 25 tratam dos limites da jurisdição nacional, estabelecendo as competências concorrente e exclusiva dos tribunais brasileiros e os casos em que o Judiciário brasileiro não será a autoridade competente para processar e julgar determinadas ações.

O artigo 21 dispõe sobre a competência concorrente da autoridade judiciária brasileira com redação praticamente idêntica à do artigo $88^{6}$ do $\mathrm{CPC} / 73^{7}$, constando como no anterior as três hipóteses: (I) quando o réu estiver domiciliado no Brasil, independentemente de sua nacionalidade; (II) quando o local de cumprimento da obrigação objeto da ação for o Brasil e (III) quando fato ocorrido no Brasil ou ato praticado no Brasil for o fundamento da ação ${ }^{8}$.

Uma novidade foi a adição ao $\mathrm{CPC} / 2015$ do artigo $22^{9}$, que traz outras hipóteses de competência concorrente dos tribunais brasileiros, não

\footnotetext{
${ }^{6} \mathrm{CPC} 1973$, Lei 5.869/1973, vigência em $1^{\circ}$ jan. 1974. Revogada pela Lei no 13.105 , de 2015.

"Art. 88. É competente a autoridade judiciária brasileira quando:

I - o réu, qualquer que seja a sua nacionalidade, estiver domiciliado no Brasil; II - no Brasil tiver de ser cumprida a obrigação;

III - a ação se originar de fato ocorrido ou de ato praticado no Brasil.

Parágrafo único. Para o fim do disposto no no I, reputa-se domiciliada no Brasil a pessoa jurídica estrangeira que aqui tiver agência, filial ou sucursal."

${ }^{7}$ Grupo de Pesquisa do Prof. Joseì Miguel Garcia Medina. Quadro comparativo entre o CPC/1973 e o $\mathrm{CPC} / 2015$ ( $2^{\mathrm{a}}$ versão) disponível em: <http://boletimjuridico.publicacoesonline.com.br/wpcontent/uploads/2015/03/Quadro-comparativo-CPC-1973-x-CPC-2015.pdf >. Acesso em 09 mar. 2017.

${ }^{8}$ CPC2015, Lei 13.105/2015, vigência em 18 mar. 2016. Assim está redigido o art. 21:

"Art. 21. Compete à autoridade judiciária brasileira processar e julgar as ações em que:

I - o réu, qualquer que seja a sua nacionalidade, estiver domiciliado no Brasil;

II - no Brasil tiver de ser cumprida a obrigação;

III - o fundamento seja fato ocorrido ou ato praticado no Brasil.

Parágrafo único. Para o fim do disposto no inciso I, considera-se domiciliada no Brasil a pessoa jurídica estrangeira que nele tiver agência, filial ou sucursal."

${ }^{9}$ CPC2015, Lei 13.105/2015, vigência em 18 mar. 2016. Assim está redigido o art. 22:
} 
previstas no $\mathrm{CPC} / 73$. Essas novas hipóteses dizem respeito a ações de alimentos, a relações de consumo e à submissão à jurisdição nacional por escolha das partes. Este último ponto, previsto no inciso III, é uma grande inovação do $\mathrm{CPC} / 2015$, pois permite a escolha do foro pelas partes, de forma expressa ou tácita. Como prevê a possibilidade das partes decidirem se vão se submeter à jurisdição nacional, fica claro que também podem optar pela jurisdição de outro Estado para julgar ações advindas de suas relações.

A competência exclusiva da autoridade judiciária brasileira é fixada pelo artigo 23 do $\mathrm{CPC} / 2015$, mais uma vez com redação parecida à do CPC/73, em seu artigo 89. No entanto, o CPC/2015 acrescenta, em seu inciso III, que o juiz brasileiro também será o único competente para "proceder à partilha de bens situados no Brasil, ainda que o titular seja de nacionalidade estrangeira ou tenha domicílio fora do território nacional" ${ }^{\prime 10}$, em casos de divórcio, separação judicial ou dissolução de união estável. O artigo 12 da Lei de Introdução às Normas do Direito Brasileiro (“LINDB”) também traz, em seu $\S 1^{\circ}$, mais um caso de competência exclusiva da autoridade judiciária brasileira, ao dispor que "só à autoridade judiciária brasileira compete conhecer das ações relativas a imóveis situados no Brasil" $" 11$.

\footnotetext{
"Art. 22. Compete, ainda, à autoridade judiciária brasileira processar e julgar as ações: I - de alimentos, quando:

a) o credor tiver domicílio ou residência no Brasil;

b) o réu mantiver vínculos no Brasil, tais como posse ou propriedade de bens, recebimento de renda ou obtenção de benefícios econômicos;

II - decorrentes de relações de consumo, quando o consumidor tiver domicílio ou residência no Brasil;

III - em que as partes, expressa ou tacitamente, se submeterem à jurisdição nacional.”

${ }^{10}$ CPC2015, Lei 13.105/2015, vigência em 18mar.2016. Assim está redigido o art. 23:

"Art. 23. Compete à autoridade judiciária brasileira, com exclusão de qualquer outra:

I - conhecer de ações relativas a imóveis situados no Brasil;

II - em matéria de sucessão hereditária, proceder à confirmação de testamento particular e ao inventário e à partilha de bens situados no Brasil, ainda que o autor da herança seja de nacionalidade estrangeira ou tenha domicílio fora do território nacional;

III - em divórcio, separação judicial ou dissolução de união estável, proceder à partilha de bens situados no Brasil, ainda que o titular seja de nacionalidade estrangeira ou tenha domicílio fora do território nacional."

${ }^{11}$ LINDB, Decreto-Lei $n^{\circ} 4.657 / 1942$. Assim está redigido o art. 12:
} 
$\mathrm{O}$ artigo 24, em correspondência com o artigo 90 do CPC/73, assenta ser a autoridade brasileira competente para conhecer de ação proposta perante tribunal estrangeiro e das causas que lhe são conexas, "ressalvadas as disposições em contrário de tratados internacionais e acordos bilaterais em vigor no Brasil”"12, uma vez que a simples propositura de ação perante o Judiciário de outro país não induz litispendência.

É importante atentar para este ponto, dado que o ordenamento jurídico brasileiro não abarca a possibilidade de litispendência internacional. Em uma situação de competência concorrente, em que sejam proferidas duas sentenças, uma por autoridade brasileira e outra por autoridade estrangeira, prevalecerá aquela que primeiro transitar em julgado. Portanto, se o Superior Tribunal de Justiça ("STJ") homologar uma sentença estrangeira, em decorrência de seu trânsito em julgado o processo com demanda idêntica ainda em curso no âmbito interno será obstado, visto que a decisão da autoridade estrangeira passará a ter efeito de coisa julgada no Brasil $^{13}$. Deste modo, resta clara a relevância do dispositivo no CPC/2015, que possibilita que autoridade judiciária brasileira conheça de causa também proposta perante a justiça estrangeira em caso de competência concorrente, salientando que não haveria litispendência internacional neste cenário.

É possível observar a aplicação desse entendimento no julgamento, realizado em 2015, da Sentença Estrangeira Contestada no 12.897 - EX

\footnotetext{
“Art. 12. É competente a autoridade judiciária brasileira, quando for o réu domiciliado no Brasil ou aqui tiver de ser cumprida a obrigação.

$\S 1$ o Só à autoridade judiciária brasileira compete conhecer das ações relativas a imóveis situados no Brasil.

§ 20 A autoridade judiciária brasileira cumprirá, concedido o exequatur e segundo a forma estabelecida pele lei brasileira, as diligências deprecadas por autoridade estrangeira competente, observando a lei desta, quanto ao objeto das diligências."

${ }^{12}$ CPC2015, Lei 13.105/2015, vigência em 18mar.2016. Assim está redigido o art. 24:

“Art. 24. A ação proposta perante tribunal estrangeiro não induz litispendência e não obsta a que a autoridade judiciária brasileira conheça da mesma causa e das que lhe são conexas, ressalvadas as disposições em contrário de tratados internacionais e acordos bilaterais em vigor no Brasil.

Parágrafo único. A pendência de causa perante a jurisdição brasileira não impede a homologação de sentença judicial estrangeira quando exigida para produzir efeitos no Brasil.”

${ }^{13}$ MANTOVANI, Denise. Há litispendência entre uma ação ajuizada no Brasil e outra no Estrangeiro? Disponível em: <https://ffg.jusbrasil.com.br/noticias/93291/ha-litispendencia-entreuma-acao-ajuizada-no-brasil-e-outra-no-estrangeiro-denise-mantovani>. Acesso em: 18 mai. 2017.
} 
(2014/0301071-1), de relatoria do Ministro Raul Araújo, que girava em torno de um pedido de homologação de sentença estrangeira proferida em Portugal, regulando o exercício do poder paternal, além de alimentos e regulamentação de visitas. A requerida, contra quem se buscava a homologação, alegou que a competência para decidir sobre matéria de ordem alimentar seria da justiça brasileira, uma vez que o menor residia no Brasil. O Ministério Público Federal ("MPF"), no entanto, se manifestou a favor da homologação, uma vez que tendo o requerente, pai do menor, domicílio em Portugal, não importa que a mãe (requerida) e o filho aqui residam, o caso será de competência concorrente das autoridades judiciárias brasileira e portuguesa.

Em seu voto, o Relator dispôs que sendo observados pela sentença os requisitos do artigo 15 da $\operatorname{LINDB}^{14}$ e dos artigos 216-A a 216-N do RISTJ, e verificando-se não haver configuração de ofensa à soberania nacional, à ordem pública e à dignidade da pessoa humana (artigo 17 da LINDB e artigo 216-F do RISTJ), deve ser homologada a sentença estrangeira. O Relator acrescentou, como havia salientado o MPF, que o caso em questão não se enquadrava nas hipóteses de competência exclusiva de autoridade judiciária brasileira e que a competência internacional concorrente "não induz a litispendência, podendo a Justiça estrangeira julgar igualmente os casos a ela submetidos, não configurado, assim, tal fato, óbice à homologação da sentença estrangeira" ${ }^{15}$. Informou ainda que, como disposto pelo artigo 90 do CPC/73 (e agora pelo artigo 24 do CPC/2015), “eventual concorrência entre sentença proferida pelo Judiciário brasileiro e

\footnotetext{
${ }^{14}$ LINDB, Decreto-Lei no 4.657/1942. Assim está redigido o art. 15:

"Será executada no Brasil a sentença proferida no estrangeiro, que reuna os seguintes requisitos:

a) haver sido proferida por juiz competente;

b) terem sido os partes citadas ou haver-se legalmente verificado à revelia;

c) ter passado em julgado e estar revestida das formalidades necessárias para a execução no lugar em que foi proferida;

d) estar traduzida por intérprete autorizado;

e) ter sido homologada pelo Supremo Tribunal Federal. (Vide art.105, I, i da Constituição Federal)."

${ }^{15}$ STJ, Corte Especial, SEC no 12.897 - EX (2014/0301071-1), Rel. Min. Raul Araújo, Brasília, j. 16 dez. 2015, DJe 02 fev. 2016.
} 
a sentença estrangeira homologada pelo STJ, sobre a mesma questão, deve ser resolvida pela prevalência da que transitar em julgado em primeiro lugar" ${ }^{16}$. Foram indicados precedentes do STJ no mesmo sentido, para demonstrarem ser este o entendimento firmado pelo Tribunal e o Relator votou pelo deferimento do pedido de homologação da sentença estrangeira. A Corte Especial do STJ, por unanimidade, deferiu o pedido nos termos do voto do Relator ${ }^{17}$.

Com este julgado, fica clara a importância do artigo 24 do CPC/2015 e demonstra-se a relevância, na prática, da não previsibilidade de litispendência internacional no ordenamento jurídico brasileiro.

A inovação do artigo 24 está em seu parágrafo único, que determina que quando a homologação de sentença judicial estrangeira for necessária para produzir efeitos no Brasil, ela poderá ocorrer independentemente da causa ainda estar pendente perante a jurisdição brasileira.

Em 2017, a Corte Especial do STJ julgou uma Sentença Estrangeira Contestada oriunda da Irlanda. O caso em questão girava em torno do descumprimento de um contrato de arrendamento de aeronaves, em que havia uma cláusula de eleição de foro submetendo as partes à jurisdição da Irlanda ou de São Paulo, caso surgissem quaisquer disputas relacionadas ao contrato. $\mathrm{O}$ julgado da Corte Especial deixa claro que, devido à existência dessa cláusula contratual, a corte irlandesa também possuía jurisdição sobre o caso e que, tratando-se de um caso de competência concorrente, não há qualquer ofensa à soberania brasileira. A ementa desse julgado explica, como dispõe o artigo 24, que a sentença transitada em julgado, proferida pelo tribunal da Irlanda, pode ser homologada, ainda que haja uma ação ajuizada perante corte brasileira envolvendo as mesmas partes, o mesmo pedido e a mesma causa de pedir. ${ }^{18}$

\footnotetext{
${ }^{16}$ STJ, Corte Especial, SEC no 12.897 - EX (2014/0301071-1), Rel. Min. Raul Araújo, Brasília, j. 16 dez. 2015, DJe 02 fev. 2016

${ }^{17}$ Ibid.

18 PROCESSO CIVIL. SENTENÇA ESTRANGEIRA CONTESTADA. AÇÃO INDENIZATÓRIA. VERBAS RECLAMADAS PELO DESCUMPRIMENTO DE
} 
O CPC/2015 trouxe, ainda, o artigo 25, sem correspondência no $\mathrm{CPC} / 73$, que prevê que os tribunais brasileiros não serão competentes para processar e julgar ações "quando houver cláusula de eleição de foro exclusivo estrangeiro em contrato internacional, arguida pelo réu na contestação"19. Esse artigo demonstra, mais uma vez, juntamente com o já mencionado inciso III do artigo 22, que o CPC/2015 reconhece expressamente a possibilidade da eleição de foro pelas partes contratantes. Esse dispositivo do CPC/2015 está em conformidade com a Convenção sobre os Acordos de Eleição do Foro $^{20}$ (Convention on Choice of Court Agreements ou “CHEF”), finalizada em 2005 na Conferência da Haia e que, como será discutido mais a frente, tem o objetivo de criar "um ambiente

OBRIGAÇÕES DECORRENTES DE CONTRATOS DE ARRENDAMENTO DE AERONAVES. DECISÃO DA JUSTIÇA IRLANDESA TRANSITADA EM JULGADO. COMPETÊNCIA DO JUÍZO FALIMENTAR BRASILEIRO. DESCABIMENTO. FORO DE ELEIÇÃO EM FAVOR DA JUSTIÇA IRLANDESA. QUESTIONAMENTO ACERCA DA EXISTÊNCIA DE DEMANDA SIMILAR NA JUSTIÇA BRASILEIRA. COMPETÊNCIA CONCORRENTE. POSSIBILIDADE DE HOMOLOGAÇÃ̃O. INEXISTÊNCIA DE OFENSA À SOBERANIA NACIONAL. PEDIDO DEFERIDO.

1. "A superveniência da decretação de falência não implica a atração do juízo falimentar sobre o processo em que proferida a sentença homologanda, na medida em que o $\S 1^{\circ}$ do art. $6^{\circ}$ da Lei $11.101 / 2005$ dispõe que as ações que demandem quantia ilíquida terão prosseguimento no juízo no qual estiverem tramitando" (AgRg na SEC 6.948/EX, Rel. Ministra Nancy Andrighi, Corte Especial, julgado em 17/12/2012, DJe 1\%/2/2013).

2. No que diz respeito à cláusula de foro de eleição, que, supostamente, obstaria a homologação pretendida, consta dos autos (e-STJ, fl. 1.601): "Este contrato, independentemente do local de sua assinatura, estará sujeito a e (sic) será interpretado de acordo com as Leis Aplicáveis, e a Arrendadora e a Arrendatária neste ato obrigam-se, irrevogavelmente, a submeter-se à jurisdição irrevogável dos Tribunais da Irlanda ou São Paulo no caso de quaisquer reclamações ou questões oriundas deste Contrato (...)". Assim sendo, verifica-se que a Justiça da Irlanda, igualmente, detinha jurisdição sobre este feito, podendo ter proferido a sentença em relação à qual se pede a homologação.

3. A existência de ação ajuizada no Brasil com as mesmas partes, o mesmo pedido e a mesma causa de pedir não obsta a homologação de sentença estrangeira transitada em julgado. Hipótese de competência concorrente (arts. 88 a 90 do Código de Processo Civil), inexistindo ofensa à soberania nacional. Precedente: AgRg na SE 4.091/EX, Rel. Ministro Ari Pargendler, Corte Especial, julgado em 29/8/2012, DJe 6/9/2012.

4. Pedido de homologação de sentença estrangeira deferido.

STJ, Corte Especial, SEC n ${ }^{\circ} 14.518$ - EX (2015/0234206-0), Rel. Min. Og Fernandes, Brasília, j. 29 mar. 2017, DJe 05 abr. 2017.

${ }^{19}$ CPC2015, Lei 13.105/2015, vigência em 18mar.2016. Assim está redigido o art. 25:

"Art. 25. Não compete à autoridade judiciária brasileira o processamento e o julgamento da ação quando houver cláusula de eleição de foro exclusivo estrangeiro em contrato internacional, arguida pelo réu na contestação.

$\S 1$ o Não se aplica o disposto no caput às hipóteses de competência internacional exclusiva previstas neste Capítulo.

$\S 20$ Aplica-se à hipótese do caput o art. 63, §§ 10 a 4o.”

20 Convenção sobre os Acordos de Eleição de Foro. Disponível em: $<$ https://www.hcch.net/pt/instruments/conventions/full-text/?cid=98>. Acesso em: 02 mar. 2017. 
jurídico mais favorável para o investimento e comércio internacional"21, ao possibilitar que as partes escolham previamente em qual ou quais foros poderão ajuizar ações para que sejam dirimidos seus conflitos.

Anteriormente à entrada em vigor do $\mathrm{CPC} / 2015$ já era admitida a utilização de cláusulas de eleição de foro estrangeiro em contratos internacionais, como estabelece o seguinte julgado de 2005:

RECURSO ESPECIAL - PREQUESTIONAMENTO - SÚMULAS 282/STF E 211/STJ - REEXAME DE PROVAS E INTERPRETAÇÃO CONTRATUAL SÚMULAS 5 E 7 - JURISDIÇÃO INTERNACIONAL CONCORRENTE ELEIÇÃO DE FORO ESTRANGEIRO - AUSÊNCIA DE QUESTÃO DE ORDEM PÚBLICA - VALIDADE - DIVERGÊNCIA NÃO-CONFIGURADA.

1. Em recurso especial não se reexaminam provas e nem interpretam cláusulas contratuais (Súmulas 5 e 7).

2. A eleição de foro estrangeiro é válida, exceto quando a lide envolver

interesses públicos. $(\ldots)^{22}$. (grifo nosso)

Ao mesmo tempo, entretanto, a jurisprudência do STJ era no sentido de que tal cláusula, apesar de válida, não afastaria a competência da autoridade judiciária brasileira para conhecer e julgar uma ação sobre a mesma questão. Isto porque, em se tratando de hipótese de competência concorrente (artigos 21 e 22 do CPC/2015), tanto a autoridade estrangeira quanto a autoridade brasileira poderiam processar e julgar a lide, e essa competência concorrente não seria excluída pela mera inserção no contrato de uma cláusula elegendo foro estrangeiro.

Essa questão foi abordada no julgamento de um Agravo Regimental no Agravo em Recurso Especial, pela Quarta Turma do STJ, em 2016. O caso tratava de um contrato de representação empresarial, firmado entre uma empresa brasileira e outra italiana, no qual constava uma cláusula de eleição de foro. Apesar da justiça italiana ter sido escolhida pelas partes, no

\footnotetext{
${ }^{21}$ Informações acerca da Convenção sobre os Acordos de Eleição de Foro disponíveis em: $<$ https://www.hcch.net/pt/instruments/conventions/specialised-sections/choice-of-court $>$. Acesso em: 02 mar. 2017.

${ }^{22}$ STJ, Terceira Turma, Recurso Especial no 242.383 - SP (1999/0115183-0), Rel. Min. Humberto Gomes de Barros, Brasília, j. 03 fev. 2005, DJ 21 mar. 2005 p. 360.
} 
contrato, para dirimir quaisquer controvérsias, o entendimento da Quarta Turma do STJ, que citou diversos precedentes para reforçar sua posição, foi que a jurisdição brasileira não seria afastada simplesmente pelo fato de haver tal cláusula contratual elegendo foro diverso, uma vez que o caso em questão se tratava de hipótese de competência internacional concorrente ${ }^{23}$.

O mesmo entendimento já havia sido demonstrado pela Quarta Turma do STJ em 2015, ao julgar um Recurso Ordinário em Ação Cautelar Preparatória, que girava em torno de um contrato entre uma sociedade empresária brasileira e um Estado estrangeiro, visando a execução de obras de edificação imobiliária no Brasil. Primeiramente, o julgado explicou que os artigos 88 a 90 do $\mathrm{CPC} / 73$ teriam o propósito de determinar a competência concorrente ou exclusiva da autoridade judiciária brasileira, mas não seriam responsáveis por designar a lei aplicável no caso concreto. Em se tratando de hipótese de competência concorrente (artigo 88 do CPC/73), as partes são livres para escolher em qual Estado desejam que ações oriundas de seu contrato sejam processadas e julgadas, através de uma cláusula de eleição de foro. Em caso de competência exclusiva da justiça brasileira (artigo 89 do $\mathrm{CPC} / 73$ ), nenhum outro Estado poderá conhecer e julgar a causa e, portanto, será ineficaz qualquer eleição de foro estrangeiro pelas partes. O julgado afirma, então, que sendo o caso em pauta enquadrado em uma hipótese de competência internacional

${ }^{23}$ AGRAVO REGIMENTAL NO AGRAVO (ART. 544 DO CPC) - AÇÃO DE COBRANÇA CUMULADA COM INDENIZATÓRIA - CONTRATO DE REPRESENTAÇÃOO EMPRESARIAL FIRMADO ENTRE UMA EMPRESA BRASILEIRA (REPRESENTANTE) E UMA ITALIANA (REPRESENTADA). FORO DE ELEIÇÃO - INDICAÇÃO DA JUSTIÇA ITALIANA PARA DIRIMIR QUALQUER CONTROVÉRSIA INERENTE AO CONTRATO COMPETÊNCIA INTERNACIONAL CONCORRENTE - SENTENÇA DE EXTINÇÃO DO PROCESSO SEM APRECIAÇÃO DO MÉRITO FUNDADA NA AUSÊNCIA DE JURISDIÇÃO BRASILEIRA - ANULAÇÃO - DELIBERAÇÃO MONOCRÁTICA QUE NEGOU PROVIMENTO AO AGRAVO EM RECURSO ESPECIAL. INSURGÊNCIA DO AGRAVANTE.

1. Para a jurisprudência do STJ, a cláusula de eleição de foro existente em contrato de prestação de serviços no exterior, portanto, não afasta a jurisdição brasileira. Precedentes: RO 114/DF, Rel. Min. Raul Araújo, DJe de 25/06/2015; EDcl nos EDcl no REsp 1159796/PE, Rel. Min. Nancy Andrighi, DJe de 25/03/2011; REsp 1.168.547/RJ, Rel. Min. Luis Felipe Salomão, DJe de 07/02/2011. (...).

STJ, Quarta Turma, AgRg no Agravo em Recurso Especial no 679.421 - RJ (2015/0060238-5), Rel. Min. Marco Buzzi, Brasília, j. 17 mar. 2016, DJe 31 mar. 2016. 
concorrente, a cláusula de eleição de foro estrangeiro é admitida. Ainda assim, aponta a Quarta Turma que a mera existência desta cláusula elegendo outro foro que não o brasileiro, não impede que tribunal brasileiro conheça e julgue a ação, se a mesma for aqui proposta, tendo em vista que a jurisdição brasileira é concorrente. ${ }^{24}$

É evidente, contudo, o desconforto gerado por esse entendimento dominante do STJ, uma vez que a cláusula de eleição de foro é empregada justamente para que as partes de um contrato tenham conhecimento prévio de qual será a lei aplicada na resolução de quaisquer conflitos oriundos de sua relação.

Demonstra-se, portanto, extremamente importante a inclusão expressa no CPC/2015 não apenas da possibilidade de partes contratantes

\footnotetext{
${ }^{24}$ RECURSO ORDINÁRIO EM AÇÃO CAUTELAR PREPARATÓRIA PROPOSTA EM FACE DE ESTADO ESTRANGEIRO (CF, ARTS. 109, II, C/C 105, II, c). PROCESSUAL CIVIL. COMPETÊNCIA INTERNACIONAL (CPC, ARTS. 88 A 90). LICITAÇÃO INTERNACIONAL. CONTRATO PARA EXECUÇÃO DE OBRAS DE EDIFICAÇÃO IMOBILIÁRIA NO BRASIL. SOCIEDADE EMPRESÁRIA BRASILEIRA E ESTADO ESTRANGEIRO. COMPETÊNCIA CONCORRENTE DA JUSTIÇA BRASILEIRA. CLÁUSULA CONTRATUAL ELETIVA DE FORO ALIENÍGENA ADMITIDA. POSSIBILIDADE DE AJUIZAMENTO DA AÇÃO NO BRASIL. COMPETÊNCIA RELATIVA (SÚMULA 33/STJ). RECURSO PROVIDO.

1. As regras de competência internacional, que delimitam a competência da autoridade judiciária brasileira com relação à competência de órgãos judiciários estrangeiros e internacionais, estão disciplinadas nos arts. 88 a 90 do Código de Processo Civil - CPC. Esses dispositivos processuais não cuidam da lei aplicável, mas sim da competência jurisdicional (concorrente ou exclusiva) do Judiciário brasileiro na apreciação das causas que indicam. 2. O art. 88 trata da denominada competência concorrente, dispondo sobre casos em que não se exclui a atuação do juízo estrangeiro, podendo a ação ser instaurada tanto perante juízo brasileiro quanto diante de juízo estrangeiro. Sendo concorrente, a competência pode ser alterada pela vontade das partes, permitindo-se a eleição de foro. 3. O art. 89 trata de ações em que o Poder Judiciário brasileiro é o único competente para conhecer e julgar a causa, com exclusão de qualquer outro. É a denominada competência exclusiva, hipótese em que a escolha do foro estrangeiro será ineficaz, ainda que resulte de expressa manifestação da vontade das partes. 4. O art. 90, por sua vez, afirma a possibilidade de atuação da autoridade judiciária brasileira mesmo no caso de existir ação intentada perante órgão jurisdicional estrangeiro. 5. A situação retratada nestes autos - ação cautelar inominada preparatória de ação para resolução de contrato cumulada com ressarcimento de perdas e danos, ajuizada por sociedade empresária brasileira em face de Estado estrangeiro enquadra-se nas hipóteses dos incisos II e III do art. 88 do CPC (cumprimento da obrigação no Brasil e ação originada de fato ocorrido no Brasil), sendo caso de competência internacional concorrente, portanto, relativa, admitindo-se a cláusula contratual de eleição de foro alienígena. 6 . Apesar de válida a cláusula de eleição de foro estrangeiro para a causa originada do contrato, isso, por si só, não exclui a jurisdição brasileira concorrente para o conhecimento e julgamento de ação aqui aforada. 7. De acordo com a Súmula $33 / \mathrm{STJ}$, "a incompetência relativa não pode ser declarada de oficio", tendo sido, portanto, precipitada a imediata extinção do processo, decretada ex officio pelo juízo singular, em razão do foro de eleição alienígena, antes mesmo da citação do Estado estrangeiro réu. 8. Recurso ordinário provido.

STJ, Quarta Turma, Recurso Ordinário no 114 - DF (2011/0027483-8), Rel. Min. Raul Araújo, Brasília, j. 02 jun. 2015, DJe 25 jun. 2015.
} 
inserirem em contratos internacionais uma cláusula elegendo o foro onde serão dirimidos seus conflitos, mas também a disposição de que, nestes casos, a autoridade judiciária brasileira não será competente. Frequentemente, devido à insegurança gerada pela via judicial, os contratantes optavam por se utilizar da arbitragem internacional; com a garantia da escolha de foro, as partes obtêm a segurança jurídica que faltava até então e, sabendo antecipadamente o local e, consequentemente, a lei que seria utilizada para solucionar possíveis disputas, podem passar a optar pela via judicial em lugar da arbitragem.

Isto posto, reputa-se necessário que o STJ modifique seu entendimento utilizado até então, demonstrado com a análise dos julgados mencionados acima, visto que o artigo 25 do CPC/2015 pacifica essa questão de forma expressa e inequívoca ${ }^{25}$.

Naturalmente, ressalta-se que não será possível a utilização da cláusula de eleição de foro do artigo 25 do CPC/2015 para escolher autoridade judiciária estrangeira como competente para solucionar as disputas das partes quando a matéria for de competência exclusiva da autoridade judiciária brasileira (artigo 23 do $\mathrm{CPC} / 2015$ ), pois isso constituiria uma clara violação à ordem pública.

Os artigos 26 a 41 do CPC/2015 versam sobre a cooperação jurídica internacional. O artigo 26 coloca que esta cooperação será regida por um tratado e, na hipótese de não haver tratado, seu $\S 1^{\circ}$ diz que a base da cooperação será a reciprocidade. Esta, por sua vez, não é necessária para que sentenças estrangeiras sejam homologadas, segundo o $\S 2^{\circ}$ do mesmo artigo. $\mathrm{O} \S 3^{\circ}$ ressalta que as normas fundamentais que regem o Estado brasileiro devem ser respeitadas na cooperação jurídica internacional, e que a prática de atos contrários à ordem pública nacional não será permitida ${ }^{26}$.

\footnotetext{
${ }^{25}$ ARAUJO, Nadia de. Direito Internacional Privado: Teoria e Prática Brasileira. $6^{\mathrm{a}}$ ed. Porto Alegre: Ed. Simplíssimo, Revolução E-book, 2016.

${ }^{26}$ CPC2015, Lei 13.105/2015, vigência em 18mar.2016. Assim está redigido o art. 26:

“Art. 26. A cooperação jurídica internacional será regida por tratado de que o Brasil faz parte e observará:
} 
O artigo 27 elenca os objetos da cooperação jurídica internacional, enquanto os artigos 28 a 34 tratam do auxílio direto e o artigo 36, da carta rogatória. Os artigos 37 a 41 definem disposições e procedimentos que se aplicam à cooperação internacional como um todo. $\mathrm{O}$ artigo 39 reforça que a cooperação jurídica internacional não ocorrerá caso seja verificada a configuração de manifesta ofensa à ordem pública ${ }^{27}$. O artigo 40 fala da homologação de sentença estrangeira que, como previsto pelo artigo 960 do CPC/2015, "será requerida por ação de homologação de decisão estrangeira, salvo disposição especial em sentido contrário prevista em tratado" 28 .

O artigo 961 traz uma informação importante ao determinar, em seu $\S 1^{\circ}$, que são passíveis de homologação as decisões que, pela lei brasileira, teriam natureza jurisdicional ${ }^{29}$, o que significa que não é preciso que a

I - o respeito às garantias do devido processo legal no Estado requerente;

II - a igualdade de tratamento entre nacionais e estrangeiros, residentes ou não no Brasil, em relação ao acesso à justiça e à tramitação dos processos, assegurando-se assistência judiciária aos necessitados;

III - a publicidade processual, exceto nas hipóteses de sigilo previstas na legislação brasileira ou na do Estado requerente;

IV - a existência de autoridade central para recepção e transmissão dos pedidos de cooperação;

$\mathrm{V}$ - a espontaneidade na transmissão de informações a autoridades estrangeiras.

$\S 1$ o Na ausência de tratado, a cooperação jurídica internacional poderá realizar-se com base em reciprocidade, manifestada por via diplomática.

§ 2o Não se exigirá a reciprocidade referida no § 1o para homologação de sentença estrangeira.

$\S 30 \mathrm{Na}$ cooperação jurídica internacional não será admitida a prática de atos que contrariem ou que produzam resultados incompatíveis com as normas fundamentais que regem o Estado brasileiro.

$\S 4 \mathrm{o}$ O Ministério da Justiça exercerá as funções de autoridade central na ausência de designação específica."

${ }^{27}$ CPC2015, Lei 13.105/2015, vigência em 18mar.2016. Assim está redigido o art. 29:

"Art. 39. O pedido passivo de cooperação jurídica internacional será recusado se configurar manifesta ofensa à ordem pública."

${ }^{28}$ CPC2015, Lei 13.105/2015, vigência em 18mar.2016. Assim está redigido o art. 960: “Art. 960. A homologação de decisão estrangeira será requerida por ação de homologação de decisão estrangeira, salvo disposição especial em sentido contrário prevista em tratado.

$\S 1$ o A decisão interlocutória estrangeira poderá ser executada no Brasil por meio de carta rogatória.

§ 20 A homologação obedecerá ao que dispuserem os tratados em vigor no Brasil e o Regimento Interno do Superior Tribunal de Justiça.

§ 3o A homologação de decisão arbitral estrangeira obedecerá ao disposto em tratado e em lei, aplicando-se, subsidiariamente, as disposições deste Capítulo."

${ }^{29}$ CPC2015, Lei 13.105/2015, vigência em 18mar.2016. Assim está redigido o art. 961: "Art. 961. A decisão estrangeira somente terá eficácia no Brasil após a homologação de sentença estrangeira ou a concessão do exequatur às cartas rogatórias, salvo disposição em sentido contrário de lei ou tratado. 
decisão seja denominada sentença para que o pedido de homologação seja apreciado. Este artigo está em conformidade com a Resolução n ${ }^{\circ}$ 9/2005 do STJ, que estabelece:

RESOLUÇÃO Nº 9, DE 4 DE MAIO DE 2005

Art. $4^{\circ} \mathrm{A}$ sentença estrangeira não terá eficácia no Brasil sem a prévia homologação pelo Superior Tribunal de Justiça ou por seu Presidente.

$\$ 1^{\circ}$ Serão homologados os provimentos não-judiciais que, pela lei brasileira, teriam natureza de sentença.

$\S 2^{\circ}$ As decisões estrangeiras podem ser homologadas parcialmente.

$\S 3^{\circ}$ Admite-se tutela de urgência nos procedimentos de homologação de sentenças estrangeiras. ${ }^{30}$ (grifo nosso).

Portanto, o que importa nesse momento de apreciação do pedido de homologação é que seja verificada a natureza da decisão e, uma vez tendo conteúdo e efeito de sentença, ainda que não seja assim intitulada em seu país de origem, a homologação poderá ocorrer. Esse é o entendimento do STJ, órgão competente ${ }^{31}$ para processar e julgar a homologação de sentenças estrangeiras, conforme prevê a Constituição Federal de 1988 em seu artigo $105^{32}$, inciso I, alínea $i$, incluída pela Emenda Constitucional $n^{\mathrm{o}}$ 45 de 2004, responsável pela transferência dessa atribuição que, até então, era do Supremo Tribunal Federal (“STF”). Isso fica demonstrado no

$\S 10$ É passível de homologação a decisão judicial definitiva, bem como a decisão não judicial que, pela lei brasileira, teria natureza jurisdicional.

$\S 20$ A decisão estrangeira poderá ser homologada parcialmente.

§ 30 A autoridade judiciária brasileira poderá deferir pedidos de urgência e realizar atos de execução provisória no processo de homologação de decisão estrangeira.

$\S 4 \mathrm{o}$ Haverá homologação de decisão estrangeira para fins de execução fiscal quando prevista em tratado ou em promessa de reciprocidade apresentada à autoridade brasileira.

§ 5o A sentença estrangeira de divórcio consensual produz efeitos no Brasil, independentemente de homologação pelo Superior Tribunal de Justiça.

$\S 60 \mathrm{Na}$ hipótese do $\S 50$, competirá a qualquer juiz examinar a validade da decisão, em caráter principal ou incidental, quando essa questão for suscitada em processo de sua competência."

30 Resolução $\mathrm{n}^{\circ} \quad 9 / 2005$ do STJ Disponível em: $<\mathrm{http}: / /$ www.stj.jus.br/SCON/legislacao/doc.jsp?livre=cartas+rogat\%F3rias\&\&b=LEGI\&p=true \&t $=\& \mathrm{l}=20 \& \mathrm{i}=1>$. Acesso em: 10 mar. 2017.

31 Atribuições do STJ. Disponível em: $<$ http://www.stj.jus.br/sites/STJ/default/pt_BR/Institucional/Atribuições>. Acesso em: 07 mar. 2017.

${ }^{32}$ CRFB1988. Assim está redigido o art. 105:

"Art. 105. Compete ao Superior Tribunal de Justiça:

I - processar e julgar, originariamente: (...)

i) a homologação de sentenças estrangeiras e a concessão de exequatur às cartas rogatórias; (Incluída pela Emenda Constitucional n 45 , de 2004)”. 
julgamento do Agravo Regimental na Sentença Estrangeira $n^{\circ} 456$, pela Corte Especial do STJ, ocorrido em 2006. O caso tratava de um pedido de homologação de sentença de divórcio consensual, proferida por autoridade japonesa; o juiz brasileiro homologou o título judicial estrangeiro, afirmando não haver ofensa à ordem pública brasileira ou aos bons costumes, assim como à soberania nacional. Esta decisão foi agravada, com base na alegação de que não estariam atendidas as exigências do artigo $4^{\circ}$ da Resolução no 9/2005 do STJ, transcrito acima.

Em seu voto, o Relator Ministro Barros Monteiro afirmou que "é cabível a homologação de divórcio por decisão de autoridade administrativa se no país de origem é esta a forma como se processa o referido ato", como determina a jurisprudência do STF (órgão que, previamente à Emenda Constitucional $\mathrm{n}^{\mathrm{o}} 45$ de 2004, era responsável pela homologação de sentenças estrangeiras, como discutido acima). O Relator incluiu precedentes que confirmam seu posicionamento, apontando um de relatoria do Ministro Marco Aurélio, no qual o mesmo declarou que "prevendo a respectiva legislação o divórcio mediante simples ato administrativo, como ocorre, por exemplo, no Japão, cabível é a homologação para que surta efeitos no território brasileiro". Deste modo, o Relator Ministro Barros Monteiro negou provimento ao Agravo Regimental, compreendendo estar satisfeita a exigência do artigo $4^{\circ}$ da Resolução $n^{\circ}$ 9/2005 do STJ, posto que, no Japão, a competência para casos de divórcio é de autoridade administrativa, que expede certidão de deferimento de registro de divórcio (presente nos autos), não havendo sentença. ${ }^{33}$

\footnotetext{
${ }^{33}$ RELATÓRIO. O SR. MINISTRO BARROS MONTEIRO:

“(...) Sustenta a agravante que o pedido de registro de divórcio consensual, ainda que equivalente à prova do trânsito em julgado da sentença homologanda, não atende às exigências do art. $4 \mathrm{o}$ da $\begin{array}{llllll}\text { Resolução } & \text { n. } & 9 / 2005 & \text { do } & \text { STJ. } & (\ldots) \text { " }\end{array}$ VOTO. O SR. MINISTRO BARROS MONTEIRO (Relator):

"1. Não prospera o inconformismo. Segundo jurisprudência firmada pelo Supremo Tribunal Federal, é cabível a homologação de divórcio por decisão de autoridade administrativa se no país de origem é esta a forma como se processa o referido ato. Nesse sentido, colhem-se os seguintes precedentes: "SENTENÇA ESTRANGEIRA - HOMOLOGAÇÃO - DIVÓRCIO - ATO ADMINISTRATIVO - EXTENSÃO. A norma inserta na alínea $h$ do inciso I do artigo $102 \mathrm{da}$ Constituição Federal, segundo a qual compete ao Supremo Tribunal Federal processar e julgar,
} 
O artigo 963 do CPC/2015, assim como o artigo $5^{\circ 34}$ da Resolução n ${ }^{o}$ 9/2005 do STJ, estabelece os requisitos indispensáveis à homologação da decisão estrangeira ${ }^{35}$. O inciso VI do artigo 963 traz novamente a importância de não haver ofensa à ordem pública interna. Caso este requisito não seja observado, a sentença estrangeira não será homologada, como dispõe também o artigo $6^{\text {o36 }}$ da assinalada Resolução $n^{\circ}$ 9/2005 do STJ.

O artigo 964 do CPC/2015, que trata de sentenças estrangeiras, deixa claro que a homologação das mesmas não ocorrerá nas hipóteses de competência exclusiva da autoridade judiciária brasileira ${ }^{37}$. Deste modo, além de verificar se estão presentes os requisitos necessários para a

originariamente, a homologação das sentenças estrangeiras, há de ser tomada respeitando-se a soberania do país em que praticado o ato. Prevendo a respectiva legislação o divórcio mediante simples ato administrativo, como ocorre, por exemplo, no Japão, cabível é a homologação para que surta efeitos no território brasileiro. (...)"

Considerando que o pedido de divórcio consensual no Japão é dirigido à autoridade administrativa competente, não havendo sentença, e sim certidão de deferimento de registro de divórcio, restou plenamente satisfeita a exigência contida no art. $4^{\circ}$ da Resolução $n^{\circ}$ 9/2005 do STJ com a apresentação pelo requerente do Pedido de Registro de Divórcio Consensual, o qual recebeu o $\mathrm{n}^{\circ}$ 105 (tradução oficial do documento às fls. 34/38).

2. Ante o exposto, nego provimento ao agravo regimental. É como voto."

STJ, Corte Especial, AgRg na Sentença Estrangeira no 456 - JP (2005/0006914-6), Rel. Min. Barros Monteiro, Brasília, j. 23 nov. 2006, DJ 05 fev. 2007 p. 171.

${ }^{34}$ STJ, Resolução n ${ }^{\circ}$, de 4 de maio de 2005.

“Art. $5^{\circ}$ Constituem requisitos indispensáveis à homologação de sentença estrangeira:

I - haver sido proferida por autoridade competente;

II - terem sido as partes citadas ou haver-se legalmente verificado a revelia;

III - ter transitado em julgado; e

IV - estar autenticada pelo cônsul brasileiro e acompanhada de tradução por tradutor oficial ou juramentado no Brasil."

${ }^{35}$ CPC2015, Lei 13.105/2015, vigência em 18mar.2016. Assim está redigido o art. 963:

“Art. 963. Constituem requisitos indispensáveis à homologação da decisão:

I - ser proferida por autoridade competente;

II - ser precedida de citação regular, ainda que verificada a revelia;

III - ser eficaz no país em que foi proferida;

IV - não ofender a coisa julgada brasileira;

V - estar acompanhada de tradução oficial, salvo disposição que a dispense prevista em tratado;

VI - não conter manifesta ofensa à ordem pública.

Parágrafo único. Para a concessão do exequatur às cartas rogatórias, observar-se-ão os pressupostos previstos no caput deste artigo e no art. 962, § 2o."

${ }^{36}$ STJ, Resolução $n^{\circ}$ 9, de 4 de maio de 2005.

"Art. $6^{\circ}$ Não será homologada sentença estrangeira ou concedido exequatur a carta rogatória que ofendam a soberania ou a ordem pública."

${ }^{37}$ CPC2015, Lei 13.105/2015, vigência em 18mar.2016. Assim está redigido o art. 964:

“Art. 964. Não será homologada a decisão estrangeira na hipótese de competência exclusiva da autoridade judiciária brasileira.

Parágrafo único. O dispositivo também se aplica à concessão do exequatur à carta rogatória.” 
homologação, o STJ deverá se certificar de que a autoridade estrangeira que proferiu a decisão não invadiu a competência exclusiva da autoridade judiciária brasileira, prevista nos já mencionados artigo 23 do CPC/2015 e artigo 12, § $1^{\circ}$ da LINDB, uma vez que, como discutido, a sentença estrangeira não poderá ser homologada nesses casos.

Como informam Nadia de Araujo e Marcelo de Nardi, neste momento “o STJ atua tão somente para delimitar a jurisdição exclusiva nacional, sem preocupação explícita e consistente com os vínculos que os submetidos à jurisdição estrangeira com ela teriam"38.

Em se tratando de matéria de competência concorrente (artigos 21 e 22 do $\mathrm{CPC} / 2015)$ da autoridade judiciária brasileira e da autoridade judiciária estrangeira, o STJ deverá analisar se há, na sentença estrangeira, algo que cause conflito com coisa julgada estabelecida no ordenamento brasileiro. Caso não haja, a sentença será homologável.

Sendo o órgão interno responsável pela homologação de sentenças estrangeiras, o STJ exerce papel fundamental na cooperação jurídica internacional. Um ponto importante sobre o papel do STJ relativo a esse campo é que, ao receber um pedido de homologação de sentença estrangeira, o órgão não poderá analisar o mérito da questão, devendo realizar uma análise puramente formal. O juízo por ele exercido deverá ser puramente delibatório: é o chamado juízo de delibação ${ }^{39}$.

Deste modo, o STJ não vai, por exemplo, analisar as cláusulas do contrato do qual trata a sentença estrangeira ou verificar se a autoridade estrangeira que proferiu a decisão objeto do pedido de homologação era ou não a competente para isto de acordo com a legislação daquele país. Assim informam Araujo e Nardi, ao explicarem que "o exame concernente à

\footnotetext{
${ }^{38}$ ARAUJO, Nadia de; NARDI, Marcelo de. Projeto de Sentenças Estrangeiras da Conferência de Haia: Por um Regime Global de Circulação Internacional de Sentenças em Matéria Civil e Comercial. Revista de Estudos Institucionais, Vol. 2, 2, 2016. p. 717.

${ }^{39}$ ARAUJO, Nadia de. Direito Internacional Privado: Teoria e Prática Brasileira. $6^{\mathrm{a}}$ ed. Porto Alegre: Ed. Simplíssimo, Revolução E-book, 2016.
} 
autoridade responsável pela sentença estrangeira se faz quanto à jurisdição do estado estrangeiro e não adentra a subdivisão interna do país"40.

No julgamento da Sentença Estrangeira Contestada $n^{0}$ 5.477, em 2015, a Corte Especial do STJ articulou que apenas o STJ tem a competência para verificar se estão presentes, na sentença estrangeira objeto do pedido de homologação, os requisitos indicados na Resolução $\mathrm{n}^{\mathbf{o}}$ 9/2005 do STJ. Além disso, afirmou expressamente que essa verificação seria realizada em mero juízo de delibação, como discutido acima. O julgado expõe, com clareza, que "não cabe nessa seara a análise das cláusulas contratuais a que se submeteram as partes, dentre elas, se se trata de contrato de adesão ou sobre a validade da cláusula de eleição de foro". ${ }^{41}$

O mesmo entendimento manifesta-se no julgamento da Sentença Estrangeira Contestada $n^{0} 11.429$, também de 2015, na qual se esclarece novamente que "para a homologação de sentença estrangeira apenas se verifica o cumprimento dos requisitos objetivos previstos, em mero juízo de delibação" ${ }^{42}$.

\footnotetext{
${ }^{40}$ ARAUJO, Nadia de; NARDI, Marcelo de. Projeto de Sentenças Estrangeiras da Conferência de Haia: Por um Regime Global de Circulação Internacional de Sentenças em Matéria Civil e Comercial. In: Revista de Estudos Institucionais, Vol. 2, 2, 2016. p. 716.

${ }^{41}$ SENTENÇA ESTRANGEIRA CONTESTADA. DIREITO CIVIL. DIVERGÊNCIAS CONTRATUAIS. COBRANÇA E GARANTIA. CUMPRIMENTO DOS REQUISITOS EXIGIDOS PELA RESOLUÇÃO 9/STJ. ALEGAÇÃO DE OFENSA À SOBERANIA NACIONAL PELA EXISTÊNCIA DA CLÁUSULA DE ELEIÇÃO DE FORO E DE INEXISTÊNCIA DE FUNDAMENTAÇÃO DA SENTENÇA. PARECER DO MPF PELA HOMOLOGAÇÃO. MERO JUÍZO DE DELIBAÇÃO. SENTENÇA ESTRANGEIRA HOMOLOGADA.

1. Nos termos da Resolução STJ 9/2005 para a homologação de sentença estrangeira somente cabe ao STJ verificar a presença dos requisitos, em mero juízo de delibação.

2. Cumpridos os requisitos previstos na Resolução STJ 9/2005, é de ser homologada a sentença estrangeira.

3. Não cabe nessa seara a análise das cláusulas contratuais a que se submeteram as partes, dentre elas, se se trata de contrato de adesão ou sobre a validade da cláusula de eleição de foro.

4. A estrutura da sentença estrangeira também não pode ser óbice à sua homologação, pois deve reger-se pela legislação alienígena e não pela lei brasileira.

5. Sentença estrangeira homologada.

STJ, Corte Especial, SEC no 5.477 - EX (2010/0095497-2), Rel. Min. Napoleão Nunes Maia Filho, Brasília, j. 06 mai. 2015, DJe 25 mai. 2015.

${ }^{42}$ SENTENÇA ESTRANGEIRA CONTESTADA. EXECUÇÃO DE ALIMENTOS FIXADOS NA AÇÃO DE DIVÓRCIO EM FAVOR DE FILHA MENOR DE IDADE. CESSAÇÃO DO PAGAMENTO. PREENCHIMENTO DOS ARTS. 216-A A 216-N DO REGIMENTO INTERNO DESTA CORTE. HOMOLOGAÇÃO 1. O pedido está em conformidade com os arts. 216-A a 216-N do RISTJ e art. 15 da Lei de Introdução às Normas do Direito Brasileiro, pois a sentença de dissolução de casamento e fixação
} 
Ainda mais recente, a ementa de processo de relatoria da Ministra Nancy Andrighi, julgado em 2017, demonstra a confirmação do mesmo, ao deferir o pedido de homologação de sentença estrangeira mencionando que o "Tribunal exerce juízo meramente delibatório nas hipóteses de homologação de sentença estrangeira; vale dizer, cabe ao STJ, apenas, verificar se a pretensão atende aos requisitos previstos no art. $5^{\circ}$ da Resolução STJ n. 9/2005 e se não fere o disposto no art. $6^{\circ}$ do mesmo ato normativo" $" 43$.

Resta claro que, como salientado, ao receber um pedido de homologação de sentença estrangeira, o STJ, único órgão com competência para admitir que uma decisão de autoridade estrangeira produza efeitos na jurisdição brasileira, no nosso sistema brasileiro de delibação concentrado,

de alimentos foi proferida por autoridade competente, as partes eram domiciliadas no estrangeiro, ambas foram citadas e compareceram aos atos necessários e ocorreu o trânsito em julgado, não havendo que se cogitar em ofensa à soberania nacional ou à ordem pública.

2. Dispensável a chancela consular, como tem entendido esta Corte, quando os documentos foram enviados diretamente pela Autoridade Estrangeira, tendo sido traduzidos por tradutor juramentado no Brasil (SEC 2.772/FR, Rel. Min. CASTRO MEIRA, DJe 5/2/2009).

3. Para a homologação de sentença estrangeira apenas se verifica o cumprimento os requisitos objetivos previstos, em mero juízo de delibação. As questões meritórias e óbices ao cumprimento das obrigações podem e devem ser discutidas perante o juízo competente de primeiro grau de jurisdição.

4. Homologação de sentença estrangeira deferida.

STJ, Corte Especial, SEC no 11.429 - EX (2014/0271818-3), Rel. Min. Napoleão Nunes Maia Filho, Brasília, j. 03 jun. 2015, DJe 04 ago. 2015.

43 PROCESSUAL CIVIL. SENTENÇA ESTRANGEIRA CONTESTADA. DIVÓRCIO. CITAÇÃO POR EDITAL. EX-CÔNJUGES. NATURAL DISTANCIAMENTO. RESIDÊNCIA. LUGAR INCERTO E NÃO SABIDO. CITAÇÃO E REVELIA. REGRAS PROCESSUAIS. NORMAS INTERNAS DE CADA PAÍS. DOCUMENTAÇÃO. CUMPRIMENTO DOS REQUISITOS DOS ARTS. $5^{\circ}$ E $6^{\circ}$ DA RESOLUÇÃO STJ N. 9/2005.

1. Controvérsia que se cinge a apreciar pedido de homologação de sentença de dissolução de vínculo matrimonial proferida pela Justiça da Inglaterra.

2. Este Tribunal exerce juízo meramente delibatório nas hipóteses de homologação de sentença estrangeira; vale dizer, cabe ao STJ, apenas, verificar se a pretensão atende aos requisitos previstos no art. $5^{\circ}$ da Resolução STJ n. 9/2005 e se não fere o disposto no art. $6^{\circ}$ do mesmo ato normativo.

3. Hipótese em que se reconhece a higidez da citação por edital, da revelia decretada no processo regido pela legislação estrangeira e a autenticidade das peças apresentadas, bem como a observância dos requisitos legais.

4. A citação e a revelia devem adotar a forma prevista na legislação do local onde o ato é praticado, seguindo as leis do país em que proferida a sentença.

5. Pedido que consiste, de fato, em mero requerimento de regularização, no Brasil, da condição de estado da requerente. Inexistência de bens a partilhar ou filhos menores a considerar.

6. Pedido de homologação de sentença estrangeira deferido.

STJ, Corte Especial, SEC no 15.004 - EX (2015/0310499-3), Rel. Min. Nancy Andrighi, Brasília, j. 15 fev. 2017, DJe 24 fev. 2017. 
não vai adentrar nas regras do Estado de origem da sentença para se certificar de que, de acordo com a legislação daquele local, a autoridade que proferiu a decisão era competente para tal. O controle realizado pelo órgão no que diz respeito a esse requisito de que a decisão tenha sido proferida por autoridade competente, apontado pelo artigo 963, I do CPC/2015 como indispensável à homologação da decisão estrangeira, limita-se à verificação de que a corte estrangeira que proferiu a sentença não invadiu a competência exclusiva da autoridade judiciária brasileira ${ }^{44}$ (artigo 23 do CPC/2015 e artigo 12, $\S 1^{\circ}$ da LINDB).

Confirmando não haver configuração de usurpação dessa competência exclusiva nacional e estando verificada a observância das demais disposições pertinentes do ordenamento brasileiro (CPC/2015, RISTJ e Resolução $n^{\circ}$ 9/2005 do STJ), assim como a presença dos já destacados requisitos necessários para a homologação, o órgão poderá deferir o pedido e homologar a sentença estrangeira.

\footnotetext{
${ }^{44}$ ARAUJO, Nadia de; NARDI, Marcelo de. Projeto de Sentenças Estrangeiras da Conferência de Haia: Por um Regime Global de Circulação Internacional de Sentenças em Matéria Civil e Comercial. In: Revista de Estudos Institucionais, Vol. 2, 2, 2016. p. 714.
} 


\section{O Projeto sobre Reconhecimento e Execução de Sentenças Estrangeiras: Judgments Project}

\subsection{Histórico do Projeto}

As negociações que deram origem ao Projeto sobre Reconhecimento e Execução de Sentenças Estrangeiras ou Judgments Project se iniciaram em 1992, quando os Estados Unidos da América enviaram à Conferência da Haia uma proposta para que fosse elaborada uma convenção que tratasse sobre jurisdição internacional e reconhecimento de sentenças estrangeiras ${ }^{45}$.

Quando da criação de uma nova convenção, é necessário determinarse se será elaborada uma convenção única ou uma convenção dupla. No caso em questão, uma convenção única (single convention) traria regras versando apenas sobre o reconhecimento e a execução de sentenças estrangeiras, mas a ideia inicial, baseada no projeto do Professor Arthur von Mehren, da Faculdade de Direito de Harvard, era que fosse criada uma convenção dupla (double convention) na qual todas as questões relativas a esses assuntos fossem regulamentadas ${ }^{46}$.

O modelo de convenção dupla, que disporia não apenas sobre o reconhecimento de decisões em matéria civil e comercial, mas também elencaria normas específicas sobre jurisdição, não obteve êxito devido a discordâncias entre os Estados. Ainda assim, as discussões e os estudos realizados até então foram aproveitados para a criação de uma convenção que trataria apenas dos acordos de escolha de foro, que se manifestam através de cláusulas de eleição de foro, em contratos internacionais entre partes empresárias. Assim, após anos de trabalho, foi concluída em 2005 a

\footnotetext{
45 Carta do Departamento de Estado dos Estados Unidos. Disponível em: $<$ https://www.state.gov/documents/organization/65973.pdf > . Acesso em: 11 mar. 2017.

${ }^{46}$ ARAUJO, Nadia de; POLIDO, Fabrício Bertini Pasquot; NARDI, Marcelo de. A Conferência da Haia e o Reconhecimento e Execução de Sentenças Estrangeiras: primeiras impressões sobre o projeto em negociação. 2016. p. 6.
} 
Convenção sobre os Acordos de Eleição de Foro ${ }^{47}$, que priorizou o reconhecimento e o respeito à autonomia da vontade das partes contratantes, que têm a possibilidade de escolher o local em que seus litígios serão solucionados ${ }^{48}$.

Como já mencionado anteriormente, a escolha da via arbitral para dirimir conflitos relativos a contratos internacionais apresentava significativas vantagens quando comparada à via judicial, uma vez que esta não oferecia segurança jurídica para as partes. O objetivo da Convenção sobre os Acordos de Eleição de Foro é justamente fornecer maior segurança jurídica às empresas que realizam negociações e transações internacionais quando estas optarem pela via judicial para a resolução de suas querelas. Consequentemente, a criação dessa Convenção também favorece a prosperidade dos negócios e do comércio internacional ${ }^{49}$.

A Convenção sobre os Acordos de Eleição de Foro tem sua aplicação restrita a contratos internacionais que versem sobre matéria civil ou comercial e que tenham uma cláusula exclusiva de eleição de foro, como define seu artigo $1^{\circ} . \mathrm{O} \S 3^{\circ}$ do mesmo artigo dispõe que "um processo tem natureza internacional quando é requerido o reconhecimento ou a execução de uma sentença estrangeira" ${ }^{\circ 0}$, mas esta Convenção não estabeleceu regras específicas relacionadas à jurisdição direta ou ao reconhecimento e

\footnotetext{
${ }^{47}$ Informações acerca da Convenção sobre os Acordos de Eleição de Foro disponíveis em: $<$ https://www.hcch.net/pt/instruments/conventions/specialised-sections/choice-of-court $>$. Acesso em: 02 mar. 2017.

${ }^{48}$ ARAUJO, Nadia de; POLIDO, Fabrício Bertini Pasquot; NARDI, Marcelo de. A Conferência da Haia e o Reconhecimento e Execução de Sentenças Estrangeiras: primeiras impressões sobre o projeto em negociação. 2016. p. 7-11.

${ }^{49}$ ARAUJO, Nadia de. Direito Internacional Privado: Teoria e Prática Brasileira. $6^{\mathrm{a}}$ ed. Porto Alegre: Ed. Simplíssimo, Revolução E-book, 2016.

50 Convenção sobre os Acordos de Eleição de Foro disponível em: $<$ https://www.hcch.net/pt/instruments/conventions/full-text/?cid=98>. Acesso em: 12 mar. 2017. Assim está redigido o artigo $1^{\circ}$ :

"1. A presente Convenção é aplicável, em processos de natureza internacional, aos acordos exclusivos de eleição do foro concluídos em matéria civil ou comercial.

2. Para efeitos do Capítulo II, um processo tem natureza internacional exceto se as partes residirem no mesmo Estado Contratante e a sua relação e todos os elementos pertinentes da causa, independentemente da localização do tribunal eleito, estiverem associados unicamente a esse Estado.

3. Para efeitos do Capítulo III, um processo tem natureza internacional quando é requerido o reconhecimento ou a execução de uma sentença estrangeira."
} 
execução de sentenças oriundas de um Estado que eram enviadas para outro Estado, onde seus efeitos deveriam se manifestar.

Ainda não havia, portanto, uma convenção que tratasse especificamente sobre tais questões e que facilitasse a circulação e a execução de sentenças estrangeiras. Deste modo, em 2010 foi retomada a discussão sobre o Judgments Project e, em 2011, com o apoio do Conselho de Assuntos Gerais e Políticos da Conferência da Haia, foi criado um Grupo de Peritos responsáveis por "avaliar a possibilidade de retomar o projeto"

Em 2012, o Conselho criou um Grupo de Trabalho, com representantes de diversos países, cujo objetivo era "preparar propostas sobre o reconhecimento e execução de decisões, que incluíssem filtros de competência" 52 . Os encontros do Grupo de Trabalho continuaram ocorrendo entre 2012 e 2015 e deram origem a um anteprojeto da convenção (draft text) que foi apresentado ao Conselho de Assuntos Gerais e Políticos. Este, por sua vez, criou então uma Comissão Especial ${ }^{53}$ para o projeto, cuja primeira reunião ocorreu em Haia, de 1 a 9 de junho de 2016, resultando em um projeto preliminar (preliminary draft convention $)^{54}$. Vale destacar que o Brasil enviou representantes para todas as reuniões e participou ativamente, como ainda participa, de todo o processo de criação do Projeto da Convenção.

Após a primeira reunião, os participantes voltaram a seus países levando as informações a respeito do discutido até então na Comissão Especial e, em 2017, retornaram à Haia para dar continuidade ao trabalho,

\footnotetext{
51 Informações sobre o Judgments Project disponíveis em: $<$ https://www.hcch.net/pt/projects/legislative-projects/judgments/>. Acesso em: 12 mar. 2017.

${ }^{52}$ Ibid.

${ }^{53}$ Council on General Affairs and Policy of the Conference (15-17 March 2016). Conclusions and Recommendations adopted by the Council. Haia: Conferência da Haia sobre Direito Internacional Privado, 2016. p. 2. Disponível em: <https://assets.hcch.net/docs/679bd42c-f974-461a-8e1a31e1b51eda10.pdf>. Acesso em: 20 mar. 2017.

${ }^{54}$ Comissão Especial sobre Reconhecimento e Execução de Sentenças Estrangeiras. 2016 Preliminary Draft Convention. Haia: Conferência da Haia sobre Direito Internacional Privado, 2016. Disponível em: <https://assets.hcch.net/docs/42a96b27-11fa-49f9-8e48-a82245affla6.pdf>. Acesso em: 20 mar. 2017.
} 
com novas propostas para o Judgments Project acerca dos temas ainda não resolvidos.

\subsection{O Projeto de 2017}

As reuniões na Holanda para tratar do Judgments Project (ou, em português, Projeto Sentenças), contaram com a participação de representantes de muitos países, diversos deles com heranças e regimes jurídicos divergentes.

A common law, utilizada por países como os Estados Unidos, Inglaterra e Austrália, tem como base principal os precedentes, ou seja, as decisões judiciais reiteradas. Desta forma, os juízes, que vão determinar quais são os precedentes que devem ser aplicados para decidir cada novo caso, possuem um papel muito importante na formação do direito. Por outro lado, o sistema da civil law (também conhecido como sistema romanogermânico) é codificado, ou seja, o direito é encontrado em códigos que compilam as leis a serem utilizadas para todos os aspectos da vida. Aqui, diferentemente de como ocorre no sistema da common law, o juiz tem o dever de analisar o caso, verificar os fatos e aplicar as normas adequadas de acordo com a legislação. Deste modo, apesar de ainda ser muito importante, o juiz que atua no sistema da civil law não tem um papel tão crucial na modelagem desta civil law, que será formulada e interpretada por legisladores e juristas ${ }^{55}$. Este é o sistema jurídico utilizado pelo Brasil, assim como por praticamente toda a América Latina, Europa, África e Ásia, sendo o mais disseminado no mundo ${ }^{56}$.

\footnotetext{
${ }^{55}$ The Common Law and Civil Law Traditions. The Regents of the University of California, The Robbins Religious and Civil Law Collection, School of Law (Boalt Hall), University of California at Berkeley. Disponível em: $<$ https://www.law.berkeley.edu/library/robbins/CommonLawCivilLawTraditions.html $>$. Acesso em 28 mai. 2017.

56 Mapa dos sistemas jurídicos utilizados no mundo disponível em: $<$ https://www.law.berkeley.edu/library/robbins/pdf/CommonLawCivilLawTraditions.pdf $>$. Acesso em: 28 mai. 2017.
} 
Tendo em vista essas diferenças básicas entre os sistemas e as divergências que suas formas de funcionamento podem gerar, entende-se que as extensas discussões na Conferência da Haia se mostraram muito importantes para possibilitar a criação de uma convenção que fosse proveitosa para todos, apesar desse vasto pluralismo jurídico entre os Estados presentes.

Considerando-se que ainda não há uma tradução oficial do projeto para o português, será realizada uma espécie de tradução livre de seus artigos, para que seja possível discuti-los a seguir. $\mathrm{O}$ texto original do Projeto de 2017 (february 2017 draft convention), em inglês, estará inteiramente disponível para consulta no anexo ao final deste trabalho.

Como assinalado anteriormente, foi decidido que seria criada uma Convenção simples, dispondo regras a serem utilizadas para o reconhecimento e a execução de sentenças estrangeiras relacionadas a questões civis ou comerciais, como estabelece o artigo $1^{\circ}$ do Projeto. Sobre o escopo da Convenção, Nadia de Araujo, Fabrício Bertini Pasquot Polido e Marcelo de Nardi lecionam que

\footnotetext{
É relevante destacar a inclusão no escopo da convenção objetivada de matérias tipicamente afetas a regulamentação normativa doméstica, tais como aquelas centradas em relações jurídicas de consumo e em contratos individuais de trabalho. Esses temas estavam expressamente excluídos do escopo da CHEF, mas foram incluídos no texto base nos últimos estágios da elaboração pelo GT, com certas restrições de aplicação quanto às referências às bases indiretas de jurisdição. ${ }^{57}$
}

Além disso, o artigo 1(2) reflete a ideia de reciprocidade da Convenção, ao determinar que ela será aplicada ao reconhecimento e execução em um Estado Contratante, de uma sentença proferida por outro Estado Contratante.

\footnotetext{
${ }^{57}$ ARAUJO, Nadia de; POLIDO, Fabrício Bertini Pasquot; NARDI, Marcelo de. A Conferência da Haia e o Reconhecimento e Execução de Sentenças Estrangeiras: primeiras impressões sobre o projeto em negociação. 2016. p. 17
} 
$\mathrm{O}$ artigo $2^{\circ}$, por sua vez, traz os âmbitos nos quais a Convenção não será aplicável, ou seja, o que está fora de seu escopo. Dentre outros, alguns exemplos são os casos relacionados ao status e capacidade legal de pessoas naturais, ao direito de família e sucessório, à insolvência, ao transporte de bens e pessoas e à difamação. No entanto, o mesmo artigo também deixa claro que caso alguma das matérias por ele enumeradas como excluídas do escopo estejam contidas em uma sentença, esta ainda poderá ser considerada passível de reconhecimento e execução, sob a Convenção, desde que as tais matérias elencadas no artigo $2^{\circ}$ figurem apenas como questões preliminares.

$\mathrm{O}$ artigo $3^{\circ}$ define termos muito utilizados na convenção: defendant, que seria o réu, e judgment, uma decisão de mérito proferida por uma corte, independentemente de como é intitulada naquele país. Como visto anteriormente, o que importa para fins de reconhecimento e execução de decisões estrangeiras é a natureza da decisão, e não sua denominação. A fixação de custas do processo pelo juízo também é considerada um judgment, desde que ela diga respeito a uma decisão de mérito que possa ser reconhecida ou executada de acordo com as normas da Convenção. No entanto, o dispositivo ressalta que a tutela provisória (interim measure) não pode ser enquadrada no conceito de judgment. Para Andrea Bonomi, a importância prática das interim measures torna decepcionante o fato de as mesmas terem sido excluídas do conceito de judgments, apesar dessa decisão ser compreensível tendo em vista as grandes diferenças entre os diversos sistemas jurídicos envolvidos ${ }^{58}$. $\mathrm{O}$ dispositivo em questão informa também as circunstâncias que caracterizariam uma entidade ou pessoa como residente habitual em um Estado.

As provisões gerais da Convenção, que deverão ser utilizadas pelos Estados para reconhecerem e executarem sentenças de outro Estado, vêm no artigo $4^{\circ}$. Ele explicita que a decisão proferida pela corte de origem não

\footnotetext{
${ }^{58}$ BONOMI, Andrea. Courage or Caution? A Critical Overview of the Hague Preliminary Draft on Judgments. Yearbook of Private International Law, Volume 17, 2015/2016. p. 6.
} 
poderá ter seu mérito revisado pela corte requerida. Apesar de discussões em torno dessa disposição, ela foi mantida no Projeto após a reunião de fevereiro de 2017. Ademais, o mesmo artigo também determina que uma decisão deverá ser reconhecida apenas se tiver efeito no Estado de origem e que só deverá ser executada se for executável no país de onde é originária; essa regra já vinha na Convenção sobre os Acordos de Eleição do Foro ${ }^{59}$, em seu artigo $8(3)$, cuja redação é idêntica à do projeto ${ }^{60}$. Por conseguinte, o artigo 4(4) estipula que a corte requerida poderá denegar o pedido de reconhecimento ou execução quando a sentença estrangeira ainda não houver transitado em julgado ou quando ainda for cabível recurso contra a mesma, garantindo então a observância do estabelecido previamente.

$\mathrm{O}$ artigo $5^{\circ}$ do Projeto versa sobre as bases para reconhecimento e execução, também chamadas de bases indiretas de jurisdição. Como salientado, a pluralidade de culturas jurídicas é um ponto que teve grande impacto nas discussões e negociações relacionadas à Convenção. Para que fosse possível a cooperação jurídica entre Estados, com o envio e o recebimento de sentenças proferidas por cortes estrangeiras, decidiu-se pela elaboração dessas bases que estabelecem critérios ou requerimentos a serem

\footnotetext{
${ }^{59}$ BEAUMONT, Paul; WALKER, Lara. Recognition and enforcement of judgments in civil and commercial matters in the Brussels I Recast and some lessons from it and the recent Hague Conventions for the Hague Judgments Project. In The Journal of Private International Law, Vol. 11, Issue 1, p. 31-63, 2015. p. 18.

${ }^{60}$ Convention on Choice of Court Agreements. Article 8 Recognition and enforcement

(1) A judgment given by a court of a Contracting State designated in an exclusive choice of court agreement shall be recognised and enforced in other Contracting States in accordance with this Chapter. Recognition or enforcement may be refused only on the grounds specified in this Convention.

(2) Without prejudice to such review as is necessary for the application of the provisions of this Chapter, there shall be no review of the merits of the judgment given by the court of origin. The court addressed shall be bound by the findings of fact on which the court of origin based its jurisdiction, unless the judgment was given by default.

(3) A judgment shall be recognised only if it has effect in the State of origin, and shall be enforced only if it is enforceable in the State of origin.

(4) Recognition or enforcement may be postponed or refused if the judgment is the subject of review in the State of origin or if the time limit for seeking ordinary review has not expired. A refusal does not prevent a subsequent application for recognition or enforcement of the judgment.

(5) This Article shall also apply to a judgment given by a court of a Contracting State pursuant to a transfer of the case from the chosen court in that Contracting State as permitted by Article 5, paragraph 3. However, where the chosen court had discretion as to whether to transfer the case to another court, recognition or enforcement of the judgment may be refused against a party who objected to the transfer in a timely manner in the State of origin.
} 
cumpridos pelas sentenças para que as mesmas possam ser reconhecidas e executadas. Isto posto, não há dúvidas quanto à importância desse artigo e das bases indiretas de jurisdição, que serão abordadas mais profundamente no próximo capítulo.

Vale destacar que, como tratado no capítulo sobre a jurisdição internacional no CPC/2015, não existem essas bases indiretas de jurisdição no direito brasileiro. Na maioria das vezes, quando o requerente demonstra, ao fazer seu pedido de homologação de sentença estrangeira, que as regras de jurisdição do local de origem da sentença foram corretamente observadas, o STJ já reconhece a competência dessa autoridade estrangeira sem maiores discussões. Nadia de Araujo, Fabrício Polido e Marcelo de Nardi destacam que

Quando há contestação do pedido de homologação da sentença estrangeira, é comum a alegação da defesa de que o juiz estrangeiro não era competente por ser o réu no Brasil domiciliado. A jurisprudência do STJ a respeito é uníssona no sentido de que por se tratar de hipótese de competência concorrente a alegação não se sustenta, e defere a homologação. ${ }^{61}$

$\mathrm{O}$ artigo $6^{\mathrm{o}}$ propõe outros critérios a serem observados no processo de reconhecimento e execução das sentenças estrangeiras; são as denominadas bases exclusivas de jurisdição. Como esclarecem Araujo e Nardi, uma análise desse dispositivo deixa claro que seu objetivo é consolidar "a obrigação dos membros da convenção de reconhecer qualquer sentença proferida segundo seus termos." ${ }^{2}$ Segundo os mesmos autores, seria um esforço no sentido de uniformizar a jurisdição direta, visto que "os Estados que aderirem à futura convenção concordarão que para os assuntos

\footnotetext{
${ }^{61}$ ARAUJO, Nadia de; MARCELO, Nardi de. POLIDO, Fabricio B. P. Reunião da próxima Comissão Especial da Conferência da Haia. Análise do Anteprojeto. Memória das negociações da $2^{\mathrm{a}}$ reunião. $9^{\mathrm{a}}$ versão, 2017. p. 11

${ }^{62}$ ARAUJO, Nadia de; NARDI, Marcelo de. Projeto de Sentenças Estrangeiras da Conferência de Haia: Por um Regime Global de Circulação Internacional de Sentenças em Matéria Civil e Comercial. Revista de Estudos Institucionais, Vol. 2, 2, 2016. p. 725.
} 
tratados no artigo $6^{\circ}$, as únicas bases jurisprudenciais aceitáveis são as lá declaradas." 63

Como informa o Presidente da Comissão Especial em suas observações introdutórias, a ideia do Projeto não é criar uma lista exaustiva de circunstâncias nas quais uma sentença poderá ser reconhecida e executada, mas apenas disponibilizar um conjunto de critérios mínimos a serem cumpridos para que sejam possíveis o reconhecimento e a execução, ou seja, apenas um núcleo comum a ser utilizado por todos os Estados membros da Convenção para ser facilitada a cooperação jurídica internacional, não impedindo a utilização de outras normas. Se os critérios estabelecidos pela Convenção forem cumpridos pela sentença, o Estado requerido será obrigado a reconhecê-la e executá-la, mas ainda que uma sentença estrangeira não observe esses requisitos estabelecidos pela Convenção, ela ainda poderá ser reconhecida e executada pelo Estado requerido, se este entender existir essa possibilidade de acordo com sua lei nacional. O Presidente da Comissão Especial acrescenta que, no entanto, existem casos em que, se os critérios estabelecidos não forem observados, não poderão ocorrer o reconhecimento e a execução da sentença ${ }^{64}$. Essas exceções estão previstas no artigo $6^{\circ}$ do Projeto:

Article 6

Exclusive bases for recognition and enforcement

Notwithstanding Article 5 -

[(a) a judgment that ruled on the registration or validity of a patent, trademark, industrial design, plant breeder's right, or similar right required to be granted or registered shall be recognised and enforced if and only if the State of origin is the State in which grant or registration has been applied for, has taken place, or is deemed to have been applied for or to have taken place under the terms of an international or regional instrument;]

(b) a judgment that ruled on rights in rem in immovable property shall be recognised and enforced if and only if the property is situated in the State of origin;

\footnotetext{
${ }^{63}$ ARAUJO, Nadia de; NARDI, Marcelo de. Projeto de Sentenças Estrangeiras da Conferência de Haia: Por um Regime Global de Circulação Internacional de Sentenças em Matéria Civil e Comercial. Revista de Estudos Institucionais, Vol. 2, 2, 2016. p. 725.

${ }^{64}$ Record of Introductory Remarks of the Chair of the Special Commission (1-9 June 2016). Fevereiro 2017. p. 5
} 
(c) a judgment that ruled on a tenancy of immovable property for a period of more than six months shall not be recognised and enforced if the property is not situated in the State of origin and the courts of the Contracting State in which it is situated have exclusive jurisdiction under the law of that State.

A alínea $a$ do artigo $6^{\circ}$ ainda está em discussão e será preciso observar os avanços nas discussões sobre este tópico.

As situações em que o reconhecimento ou a execução das sentenças estrangeiras poderão ser recusados vêm indicadas no artigo $7^{\circ}$. Como exemplos, podem ser citadas, entre outras: obtenção da sentença através de fraude; incompatibilidade manifesta com a ordem pública do Estado requerido (compatível com o artigo 963, VI do CPC/2015); sentença inconsistente com decisão do Estado requerido em uma disputa entre as mesmas partes (este ponto também demonstra compatibilidade com o ordenamento brasileiro, uma vez que o artigo 963, IV do CPC/2015 determina a impossibilidade de ser homologada uma decisão que ofenda a coisa julgada brasileira). $\mathrm{O}$ artigo traz, ainda, a possibilidade de recusa ao reconhecimento ou execução de uma sentença que seja inconsistente com outra, proferida em momento anterior, por outro Estado (que não o requerido, nem o requerente), em uma demanda envolvendo as mesmas partes. Nadia de Araujo aponta que esse dispositivo está afirmando a existência da coisa julgada internacional, com uma sentença proferida por um Estado podendo fazer coisa julgada no Estado requerido; destaca ainda que, apesar desse conceito ser inexistente no direito brasileiro, não seria incompatível com nosso ordenamento ${ }^{65}$.

Percebe-se, portanto, que as circunstâncias elencadas por esse dispositivo como aquelas que podem levar à recusa estão relacionadas basicamente à ofensa à ordem pública, à incompatibilidade de sentenças ou à violação de requisitos formais por parte da sentença em questão.

\footnotetext{
${ }^{65}$ ARAUJO, Nadia de; MARCELO, Nardi de. POLIDO, Fabricio B. P. Reunião da próxima Comissão Especial da Conferência da Haia. Análise do Anteprojeto. Memória das negociações da $2^{\mathrm{a}}$ reunião. $9^{\mathrm{a}}$ versão, 2017.
} 
Paul Beaumont, membro da delegação da União Europeia que participa dos trabalhos acerca do Judgments Project na Conferência da Haia, e Laura Walker, comentaram sobre a questão da ofensa à ordem pública antes mesmo da primeira reunião em 2016, destacando que não é possível garantir que todos os ordenamentos jurídicos dos Estados envolvidos no projeto apliquem o mesmo conceito de public policy, o que, naturalmente, pode levar a complicações ${ }^{66}$. Assim, os autores sugerem como uma forma de contribuir para a uniformização dessa interpretação, a inclusão, em um relatório anexo à Convenção, de exemplos do que seria considerado uma fraude processual de modo que, quando forem utilizar a Convenção para o reconhecimento ou a execução de sentenças estrangeiras, as cortes dos Estados possam verificar se ocorreu a tal fraude, que já seria, no entendimento dos autores, um tipo de violação à ordem pública; não seria necessário, portanto, que houvesse na Convenção uma previsão como a do artigo $7^{\circ}$, discutido anteriormente, indicando a fraude processual como um dos motivos para a recusa do pedido de reconhecimento ou execução de sentenças, já que quaisquer abusos de procedimento (abuses of procedure) estariam englobados pela ofensa à ordem pública ${ }^{67}$.

Ao mesmo tempo, Beaumont e Walker são a favor da inserção da hipótese de sentenças incompatíveis ou irreconciliáveis (irreconcilable judgments) como motivo para a recusa ${ }^{68} . \mathrm{O} \S 1^{\circ}$ do artigo $7^{\circ}$ refere-se a isso em suas alíneas $e$ e $f$, apesar de utilizar o termo "inconsistente":

Article 7

Refusal of recognition or enforcement

1. Recognition or enforcement may be refused if - (...)

(e) the judgment is inconsistent with a judgment given in the requested State in a dispute between the same parties; or

\footnotetext{
${ }^{66}$ BEAUMONT, Paul; WALKER, Lara. Recognition and enforcement of judgments in civil and commercial matters in the Brussels I Recast and some lessons from it and the recent Hague Conventions for the Hague Judgments Project. In The Journal of Private International Law, Vol. 11, Issue 1, p. 31-63, 2015. p. 13.

${ }^{67}$ Ibid. p. 15.

${ }^{68}$ Ibid.
} 
(f) the judgment is inconsistent with an earlier judgment given in another State between the same parties on the same subject matter, provided that the earlier judgment fulfills the conditions necessary for its recognition in the requested State; (...).

Questões preliminares são discutidas no artigo $8^{\circ}$, que indica outros casos nos quais o reconhecimento ou a execução de sentenças estrangeiras não ocorrerá. Basicamente, são situações envolvendo matérias que fogem do escopo da Convenção ou que estão mencionadas no artigo $6^{\circ}$ e cujo julgamento não observou o previsto por este dispositivo.

A equivalência de efeitos é inserida pelo artigo $9^{\circ}$. Este estabelece, primeiramente, que uma sentença reconhecível ou executável deverá ter, no Estado que recebê-la, os mesmos efeitos que teria em seu Estado de origem. Caso não haja essa possibilidade, devido à falta de previsão legal no ordenamento jurídico do Estado requerido, deverá ser realizada uma adaptação para que os efeitos da sentença sejam equivalentes, ainda que não idênticos, mas sem ultrapassarem os efeitos previstos pela lei do Estado onde foi proferida.

O artigo 10 versa sobre a divisibilidade de uma decisão, especificando que existe a possibilidade de apenas parte da sentença ser reconhecida e executada, caso seja este o requerido ou caso, ao analisar a sentença, perceba-se que somente parte da mesma é passível de reconhecimento ou execução, de acordo com o estipulado pela Convenção.

$\mathrm{O}$ artigo 11 trata da indenização. Afirma que o reconhecimento ou a execução de uma sentença poderão ser recusados em uma situação na qual a sentença conceda uma indenização, inclusive a indenização punitiva (punitive damages), que não seja capaz de compensar a parte pela perda ou prejuízo sofrido.

Ainda está em discussão o artigo 12, que trata de casos envolvendo propriedade intelectual, em que não há indenização monetária (nonmonetary remedies). De acordo com o projeto de 2017, não seria cabível a execução de uma sentença concedendo indenização de outra natureza que não a monetária; apenas sentenças contendo indenizações monetárias 
podem circular. Será preciso observar os avanços nas discussões e possíveis modificações propostas na próxima reunião, para verificarmos se esse artigo será ou não incluído no texto final da Convenção.

O artigo 13 fala sobre acordos ou transações judiciais aprovadas por um Estado Contratante ou concluídos perante a corte de um Estado Contratante e estipula que, sendo esses acordos ou transações executáveis no Estado de origem da mesma forma que seria uma sentença, deverão também os mesmos serem executados segundo as normas da Convenção. O Projeto apresenta também com uma condição, ainda em discussão, que limitaria o disposto até então nesse artigo, ao colocar que para a execução desses acordos ou transações ocorrer, seria necessário que eles fossem permitidos pela lei do Estado requerido.

Os documentos a serem produzidos quando do requerimento de reconhecimento ou execução são apontados pelo artigo 14. Os artigos 15 e 16 abordam os procedimentos e as custas procedimentais, respectivamente.

Analisando esses dispositivos, Nadia de Araujo destaca que, ao determinar que as regras utilizadas para o procedimento serão as do Estado requerido (salvo previsão diversa na Convenção, como é o caso do já discutido artigo $6^{\circ}$ ), o artigo 15 está reiterando a regra de lex fori, já utilizada universalmente. No entanto, a autora ressalta que é possível surgirem problemas com relação à essa norma, devido à grande pluralidade jurídica entre os Estados participantes. Para aqueles que utilizam o sistema da common law, por exemplo, a prescrição (statute of limitations) é vista como uma questão de direito processual, diferentemente do direito brasileiro, que a classifica como uma questão de direito material ${ }^{69}$. Todavia, Andrea Bonomi enfatiza ser prudente essa escolha por não se introduzir um procedimento uniforme para o reconhecimento e a execução, pois assim é

\footnotetext{
${ }^{69}$ ARAUJO, Nadia de; MARCELO, Nardi de. POLIDO, Fabricio B. P. Reunião da próxima Comissão Especial da Conferência da Haia. Análise do Anteprojeto. Memória das negociações da $2^{\mathrm{a}}$ reunião. $9^{\mathrm{a}}$ versão, 2017.
} 
evitada uma interferência muito profunda nos sistemas nacionais dos Estados $^{70}$.

$\mathrm{O}$ artigo 17 esclarece que a Convenção não impede $\mathrm{o}$ reconhecimento ou a execução de sentenças sob a lei nacional, mas que devem ser respeitadas as bases exclusivas de jurisdição, previstas no artigo 6. Bonomi explica que esse dispositivo segue a abordagem utilizada na maioria dos instrumentos internacionais sobre reconhecimento e execução de sentenças estrangeiras, e que a ideia de se possibilitar essa aplicação de leis nacionais, quando forem mais adequadas, deriva do desejado objetivo de se facilitar a circulação de decisões. A autora destaca a importância dessa norma que institui a não-exclusividade pois acredita existir a possibilidade de que a lei de alguns Estados Contratantes seja, com relação à diversas questões e pontos da Convenção, mais oportuna para um reconhecimento mais facilitado de sentenças estrangeiras, do que as próprias regras da futura Convenção ${ }^{71}$.

A reunião de fevereiro de 2017 foi responsável pela elaboração dos artigos 18 em diante, que não constavam no projeto preliminar (draft text) de 2016. Os artigos 18 a 26 integram o Capítulo III, responsável pelas cláusulas gerais da Convenção. O Capítulo IV, que engloba os artigos 27 a 34 , trata das cláusulas finais.

O artigo 18 demonstra sua importância ao clarificar quando a Convenção será aplicável. Segundo este dispositivo, a mesma será empregada para o reconhecimento e a execução de sentenças se ela já estiver em vigor tanto no Estado requerente, onde foi originada a sentença, quanto no Estado requerido, no momento em que os procedimentos forem instituídos no Estado de origem.

Ainda sob debate está o artigo 19, que fala mais uma vez sobre documentos. A redação atual permite que sejam utilizados documentos sem

\footnotetext{
${ }^{70}$ BONOMI, Andrea. Courage or Caution? A Critical Overview of the Hague Preliminary Draft on Judgments. Yearbook of Private International Law, Volume 17 (2015/2016). p. 11-12.

${ }^{71}$ Ibid. p. 7.
} 
a necessidade de serem previamente legalizados ou passarem por qualquer outra formalidade análoga.

Os artigos 20, 21 e 22 tratam de declarações. O primeiro, de declarações limitando o reconhecimento ou a execução, especifica que no caso das partes serem residentes do Estado requerido e o relacionamento entre elas e todos os outros elementos relevantes à disputa estarem conectados apenas ao Estado requerido (exceto a corte do Estado de origem), o Estado pode permitir que suas cortes recusem o reconhecimento ou a execução de uma sentença proferida por outro Estado Contratante.

O artigo 21 traz declarações que dizem respeito a assuntos específicos e esclarece que, caso um Estado tenha forte interesse na não aplicação da Convenção em uma matéria ou assunto específico, poderá declarar que não o fará. Ressalta-se que esta declaração não deve ser mais ampla do que o necessário e que a matéria excluída naquela situação deve ser definida com precisão e clareza. Além de não ser aplicada no Estado que fez tal declaração, a Convenção também não será empregada em outros Estados Contratantes quando estiverem diante de um pedido de reconhecimento ou execução de sentença originária do Estado que forjou a declaração.

Em seguida, são discutidas no artigo 22 declarações que dizem respeito a cortes comuns. Um Estado Contratante pode declarar que uma corte comum a dois ou mais Estados tem jurisdição para julgar matérias dentro do escopo da Convenção. Nesse caso, também especificará se essa corte tem a função de julgar em primeira instância e em instância recursal, ou se tem apenas a função de apreciar os recursos. O dispositivo em questão informa, ainda, o que seria considerado uma sentença de Estado Contratante. Ademais, o $\S 3^{\circ}$ do artigo expõe que na hipótese de uma corte que julgue apenas recursos ser uma corte comum entre Estados Contratantes e não-Contratantes, as sentenças proferidas por tal corte somente serão consideradas sentenças de um Estado Contratante se os procedimentos em primeira instância tiverem ocorrido também em um 
Estado Contratante. Já se for o caso de uma corte comum que tenha jurisdição em primeira instância e em grau recursal, as referências ao Estado de origem contidas nos artigos $5^{\circ}$ e $6^{\circ}$, que tratam das bases indiretas de jurisdição e das bases exclusivas de jurisdição, respectivamente, devem ser compreendidas como se referindo à totalidade do território sob o qual aquela corte tinha jurisdição no caso da sentença em questão. Vale mencionar que o artigo 22 ainda poderá sofrer mudanças nas próximas reuniões a tratarem do Projeto, posto que ainda existem dúvidas em relação ao mesmo.

O artigo 23 fala sobre a importância da aplicação uniforme da Convenção, com seu caráter internacional, e o artigo 24 aponta a necessidade de se revisar a Convenção e seu funcionamento, tarefa esta cuja competência é do Secretário-Geral da Conferência da Haia de Direito Internacional Privado.

A questão dos sistemas jurídicos não unificados é abordada pelo artigo 25, que coloca critérios a serem observados pelos Estados Contratantes que, em suas diferentes unidades territoriais, apliquem dois ou mais sistemas jurídicos distintos no que tange matérias relacionadas à Convenção. O dispositivo determina que qualquer referência feita na Convenção à lei ou procedimento de um Estado, à residência habitual em um Estado, à corte ou cortes de um Estado e à uma conexão com um Estado, deve ser interpretada, onde apropriado, como referente àquela unidade territorial em questão. Além disso, é esclarecido que a Convenção não precisa ser obrigatoriamente aplicada em situações envolvendo apenas as unidades territoriais de um Estado e seus diferentes sistemas jurídicos. Salienta-se também que a decisão de uma corte de uma unidade territorial não vincula as outras pertencentes ao mesmo Estado Contratante; ainda que uma delas reconheça ou execute uma sentença originária de outro Estado, com base na Convenção, as cortes das outras unidades territoriais do mesmo Estado decidirão de forma independente, não sendo obrigadas a deferir o pedido somente devido à decisão favorável daquela corte. Essa 
situação sobre a qual discorre o artigo 25 é concernente principalmente ao Canadá.

O dispositivo seguinte, artigo 26, traz considerações sobre o relacionamento da Convenção com outros instrumentos internacionais. Primeiramente, expõe que a interpretação da Convenção deve ser feita da forma mais ampla possível, para que seja compatível com outros tratados em vigor para os Estados Contratantes; para esse ponto, não importa se a conclusão desses instrumentos ocorreu antes ou depois da Convenção. O dispositivo instrui que a Convenção não deverá afetar a aplicação de um tratado que tenha sido concluído ou revisado antes da entrada em vigor da Convenção para o Estado Contratante. Uma exceção apontada é o caso de o tratado ser revisado e modificado, surgindo então inconsistências com a Convenção, após a entrada em vigor da Convenção para o referido Estado Contratante. Em se tratando dos objetivos de obter o reconhecimento ou a execução de uma sentença proferida por uma corte de um Estado Contratante que também é parte de um tratado, a Convenção também não afetará a aplicação desse outro instrumento internacional. Entretanto, a sentença não deve ser reconhecida ou executada em menor grau do que seria de acordo com a Convenção. Um tratado que verse sobre reconhecimento ou execução de sentenças com relação a uma matéria específica não terá sua aplicação obstada pela Convenção, ainda que tenha sido concluído após a mesma e ainda que todos os Estados interessados sejam Partes na Convenção. Cabe ressaltar que, no entanto, para que essa disposição seja aplicada, é preciso que o Estado Contratante faça uma declaração a respeito do tratado e dessa questão. Desta forma, não havendo nenhuma outra inconsistência entre a Convenção e o tratado, outros Estados Contratantes terão a liberdade de decidir se desejam ou não aplicar a Convenção no caso de uma sentença relacionada à matéria específica abordada pelo tratado.

O Capítulo IV do Projeto é iniciado com o artigo 27, que trata da assinatura, ratificação, aceitação, aprovação ou adesão à Convenção por 
parte dos Estados. O artigo 28 discorre sobre declarações relativas a sistemas jurídicos não unificados; um Estado com duas ou mais unidades territoriais, que utilizem sistemas jurídicos distintos, pode declarar se a Convenção será aplicada em todas as unidades territoriais ou em apenas uma ou algumas delas. Caso essa declaração não seja feita, será entendido que a Convenção se aplica a todas as unidades territoriais que compõem aquele Estado.

O dispositivo seguinte versa sobre as Organizações Regionais de Integração Econômica (Regional Economic Integration Organisations) às quais não são aplicadas as normas dispostas pelos artigos 25 e 28 , ambos responsáveis por abordar questões relacionadas aos sistemas jurídicos não unificados. De acordo com o artigo 29, uma organização desse tipo também poderá, assim como os Estados (artigo 27), assinar, aceitar, aprovar ou aderir à Convenção, desde que tal organização seja constituída apenas por Estados soberanos e possua competência sobre algumas ou todas as matérias tratadas pela Convenção. Com isso, a organização gozará dos direitos e estará submetida ao cumprimento das obrigações de um Estado Contratante. Ressalta-se que no momento de sua assinatura, aceitação, aprovação ou adesão, a Organização Regional de Integração Econômica deverá especificar, por escrito, quais são as matérias, dentre as que se enquadram no escopo da Convenção, que tiveram sua competência transferida pelos Estados para essa organização à qual pertencem; além disso, também deverão ser notificadas quaisquer mudanças relativas às competências da organização.

O artigo 29 , em seu $\S 3^{\circ}$, faz referência ao artigo 30 , explicitando que a organização precisará declarar que seus Estados-membros não serão Partes na Convenção, para que o instrumento depositado por essa organização seja contabilizado para efeitos da entrada em vigor da Convenção. Destaca-se que, para fins de aplicação da Convenção, será realizada uma equiparação prevista no $\S 4^{\circ}$ : as disposições que mencionam os termos "Estado" ou "Estado Contratante" serão igualmente aplicadas a 
essas organizações, onde apropriado, salvo quando, como exemplificado anteriormente, houver uma disposição expressa em contrário.

Tal como assinalado acima, o artigo 30 comenta sobre Organizações Regionais de Integração Econômica que aderem à Convenção sem seus Estados-membros. Caso a organização possua competência sobre todas as matérias que se enquadram no escopo da Convenção, ela poderá declarar, no momento da assinatura, aceitação, aprovação ou adesão, que seus Estados-membros não serão Partes na Convenção, mas estarão sujeitos à mesma em virtude da referida assinatura, aceitação, aprovação ou adesão por parte da organização. $\mathrm{O} \S 2^{\circ}$ deste mesmo artigo traz, assim como o artigo 29, uma equiparação para fins de aplicação da Convenção, mas, desta vez, com relação aos Estados Contratantes (que podem ser chamados tanto de "Estado" quanto de "Estado Contratante") e os Estados-membros da organização.

O artigo 31 traz informações acerca da entrada em vigor da Convenção, enquanto o artigo 32 oferece mais especificações sobre as declarações mencionadas nos artigos 20, 21, 26(4), 28 e 30 (declarações limitando o reconhecimento ou a execução, declarações que dizem respeito a assuntos específicos, declarações sobre tratados e sua aplicação, declarações relativas a sistemas jurídicos não unificados e declarações relacionadas a Organizações de Integração Econômica Regional, respectivamente).

O artigo 33, por sua vez, é dedicado à denunciação da Convenção, discorrendo sobre como ela deverá ser feita e quando surtirá efeitos. Destaca também que no caso de um Estado com múltiplas unidades territoriais e um sistema jurídico não unificado, a denunciação poderá se limitar a apenas algumas das unidades territoriais. Finalizando, o artigo 34, último do Projeto de fevereiro de 2017, pronuncia-se sobre notificações que deverão ser feitas pelo depositário.

Está prevista para novembro de 2017 a próxima reunião da Comissão Especial em Haia, para dar continuidade às discussões acerca da 
Convenção ${ }^{72}$. Até lá, os participantes continuarão trabalhando em possíveis sugestões e ideias que possam introduzir ao debate, assim como em proposições que atendam aos interesses de seus países e que possam auxiliar na resolução das controvérsias ainda existentes.

\footnotetext{
72 Overview of the Judgments Project. Disponível em:
} $<$ https://www.hcch.net/pt/projects/legislative-projects/judgments>. Acesso em: 16 abr. 2017. 


\section{Parte II}

\section{Bases Indiretas de Jurisdição}

Como salientado anteriormente, a Comissão Especial responsável pela elaboração do Judgments Project é composta por representantes de diversos países, muitos com sistemas jurídicos distintos e ordenamentos jurídicos com regras que nem sempre são compatíveis; isso, naturalmente, gera muitas discussões com relação às normas que serão inseridas na Convenção.

No capítulo sobre a jurisdição internacional no Código de Processo Civil de 2015, foram apontadas as regras do nosso ordenamento a serem utilizadas pelo STJ quando este se depara com casos de sentenças estrangeiras cujo reconhecimento e execução se dariam no Brasil.

Com o objetivo de demonstrar brevemente como as diferenças entre os ordenamentos jurídicos envolvidos no Projeto podem resultar em dificuldades, os Estados Unidos serão aproveitados como exemplo. O país utiliza o sistema de governo chamado de Federalismo ${ }^{73}$ (assim como o Brasil), e seus estados possuem grande autonomia, garantida pela Constituição ${ }^{74}$. Nos Estados Unidos, a fonte de direito utilizada no momento do reconhecimento ou da execução de uma sentença estrangeira é a common e statutory law ${ }^{75}$ estadual; isso significa, portanto, que as regras

\footnotetext{
${ }^{73}$ Sistema político em que organizações políticas (como estados, municípios, províncias, etc.) se unem, formando uma organização maior, com um governo central e federal que governa a todos. Esses integrantes, ao se unirem, mantêm sua autonomia.

${ }^{74}$ Constitution of the United States. Amendment X (1791)

The powers not delegated to the United States by the Constitution, nor prohibited by it to the States, are reserved to the States respectively, or to the people. Disponível em: $<$ https://www.senate.gov/civics/constitution_item/constitution.htm\#amendments>. Acesso em: 14 abr. 2017.

${ }^{75}$ A common law consiste no direito que se consolida em decorrência da reiteração de decisões e julgamentos realizados pelo Poder Judiciário, que formam precedentes; é também chamada de case law. A statutory law, por sua vez, se solidifica em leis escritas (sendo, portanto, chamada também de written law), criadas pelo Poder Legislativo (ou outras agências governamentais), que não dependem de precedentes para serem aplicadas. Nos Estados Unidos, a common law é utilizada para auxiliar na interpretação da statutory law. (POJANOWSKI, Jeffrey A. Reading
} 
podem variar de um estado para outro, o que gera confusão e dificuldades, como explica Ronald Brand:

\begin{abstract}
The fact that the source of judgments recognition law in the United States moved from federal common law to state common and statutory law in the early twentieth century now results in significant substantive law differences from state to state. Recent decisions indicate the problems created by those substantive law differences. In addition, state law differences in applying both Constitutional principles of due process to questions of personal jurisdiction in the recognizing court, and the doctrine of forum non conveniens, add additional opportunities for forum shopping and manipulation in ways that create both inefficiencies and inequities. The resulting litigation strategies that exist simply because of these differences among the states demonstrate a difficult-to-justify legal framework for the recognition of judgments in U.S. courts. ${ }^{76}$
\end{abstract}

O autor acredita que o ideal seria que lei federal pautasse o reconhecimento de sentenças estrangeiras, em uma tentativa não apenas de se obter um sistema unificado de regras a serem utilizadas nesse momento de reconhecimento, mas também com o objetivo de se desencorajar o forum shopping $^{7778}$.

Nos Estados Unidos, os tribunais utilizam regras de competência interna quando se deparam com pedidos de reconhecimento de sentenças estrangeiras; essas regras, o local de residência do réu e o local em que o réu foi citado (em certas circunstâncias), são definidas pela reiteração de

Statutes in the Common Law Tradition. Virginia Law Review. 2015, volume 101, issue 5.) Disponível em: <http://www.virginialawreview.org/volumes/content/reading-statutes-commonlaw-tradition>. Acesso em: 30 mai. 2017.

${ }^{76}$ BRAND, Ronald. The Continuing Evolution of US Judgments Recognition Law. Legal Studies Research Paper Series Working Paper No. 2015-37. University of Pittsburgh School of Law. 2015. p. 70

Tradução livre da autora: O fato de que a fonte do direito sobre reconhecimento de sentenças nos Estados Unidos foi transferida da common law federal para a common e statutory law estadual no início do século XX agora resulta em significativas diferenças de direito substantivo (ou material) de estado para estado. Decisões recentes indicam os problemas criados por essas diferenças de direito substantivo. Em adição, a lei estadual se diferencia na aplicação de princípios constitucionais do due process para questões de jurisdição pessoal no tribunal do reconhecimento, e na doutrina do forum non conveniens, adiciona oportunidades adicionais para o forum shopping e manipulação de forma que são criadas ineficiências e desigualdades. As estratégias de litígio resultantes que existem simplesmente devido a essas diferenças entre os estados demonstram um quadro jurídico para o reconhecimento de sentenças em cortes americanas difícil de se justificar.

${ }^{77} \mathrm{O}$ forum shopping é a busca e escolha realizada pelas partes, em um caso de competência concorrente, pelo foro que lhes parece mais provável de conceder um resultado mais favorável à sua disputa. (ARAUJO, Nadia de. Direito Internacional Privado: Teoria e Prática Brasileira. Ed. Simplíssimo, Revolução E-book, 2016).

${ }^{78}$ BRAND, Ronald. Op. Cit. p. 70. 
decisões judicias, como ocorre nos sistemas da common law, e as normas utilizadas para esse tema vêm da cláusula constitucional do due process of law. Seus tribunais não possuem um conjunto de critérios para guiá-los nesse momento, mas apenas essas duas regras que são usadas para determinar se o juiz estrangeiro que proferiu a decisão era competente para tal. Para os americanos, portanto, bastaria que a Convenção fizesse uma referência a esse tipo de cláusula, não sendo preciso estabelecer hipóteses específicas nas quais a jurisdição estrangeira seria reconhecida ${ }^{79}$.

Essa discussão sobre a competência do juiz estrangeiro não é uma realidade no Brasil; não é feita essa verificação sobre a jurisdição exercida pelo juiz de outro Estado, como instruem Araujo, Polido e Nardi:

No Brasil, admite-se, sem qualquer questionamento, a regra de que cabe ao juiz estrangeiro determinar a sua competência, e esta determinação será respeitada no momento do reconhecimento e execução da decisão estrangeira, no caso, o processamento da ação de homologação segundo a competência originária do Superior Tribunal de Justiça. ${ }^{80}$

É perceptível, portanto, o impacto que as diferentes normas para reconhecimento e execução de sentenças estrangeiras utilizadas pelos países que participam da Comissão Especial e que, espera-se, se tornarão Estados Contratantes da Convenção, podem causar não somente nos debates para a criação do Projeto, mas também na real eficiência da futura Convenção.

Como ressalta o Presidente da Comissão Especial em suas observações introdutórias, deseja-se que a Convenção seja utilizada no maior número possível de oportunidades e, para que isso seja atingido, é preciso um esforço para se alcançar um meio termo: não fazer uma Convenção com regras tão abrangentes que não sejam aceitas pelos Estados

\footnotetext{
${ }^{79}$ ARAUJO, Nadia de; POLIDO, Fabrício Bertini Pasquot; NARDI, Marcelo de. A Conferência da Haia e o Reconhecimento e Execução de Sentenças Estrangeiras: primeiras impressões sobre o projeto em negociação. 2016. p. 18-19.

${ }^{80}$ Ibid. p. 18.
} 
Contratantes, mas também não restringi-la excessivamente, à ponto de que só possa ser aplicada em alguns poucos $\operatorname{casos}^{81}$.

Assim, para que seja maximizado o alcance da Convenção e ela proporcione melhorias substanciais para o reconhecimento e a execução de sentenças estrangeiras, sendo efetivamente relevante no cenário internacional apesar das diversas culturas jurídicas existentes, foi definido que deveriam ser estabelecidos critérios padronizados de jurisdição indireta a serem utilizados por todos os Estados Contratantes. São as bases indiretas de jurisdição que, como ensinam Araujo, Polido e Nardi, consistem basicamente em

\begin{abstract}
hipóteses de competência internacional que devem ser respeitadas pelo juízo do Estado de origem para que sua decisão possa ser posteriormente reconhecida no Estado requerido. Com isso se evitam os problemas advindos de decisões proferidas em foros cujas regras de competência interna são consideradas exorbitantes (como simplesmente estar presente o réu em determinado lugar ao tempo da citação para o processo, e em alguma medida a nacionalidade do réu, entre outros). ${ }^{82}$
\end{abstract}

Deste modo, a ocorrência de alguma das hipóteses previstas no artigo das bases indiretas de jurisdição garante que o tribunal requerido aceitará a legitimidade do exercício da jurisdição pela corte daquele Estado que enviou a sentença, sem a necessidade de se realizar um exame para verificar se aquela corte realmente possuía competência para tal ${ }^{83}$.

A questão das bases indiretas de jurisdição gerou muitos debates no Grupo de Trabalho, e o artigo $5^{\circ}$ do Projeto ainda é objeto de discussões na Comissão Especial, exatamente por se tratar de um tema tão essencial para a Convenção e pelo fato de que os participantes das negociações precisam se esforçar para alcançar um consenso no que tange os critérios e limites

\footnotetext{
${ }^{81}$ Record of Introductory Remarks of the Chair of the Special Commission (1-9 June 2016). Haia: Conferência da Haia de Direito Internacional Privado, 2017. p. 8.

${ }^{82}$ ARAUJO, Nadia de; POLIDO, Fabrício Bertini Pasquot; NARDI, Marcelo de. A Conferência da Haia e o Reconhecimento e Execução de Sentenças Estrangeiras: primeiras impressões sobre o projeto em negociação. 2016. p. 13.

${ }^{83}$ ARAUJO, Nadia de; MARCELO, Nardi de. POLIDO, Fabricio B. P. Reunião da próxima Comissão Especial da Conferência da Haia. Análise do Anteprojeto. Memória das negociações da $2^{\mathrm{a}}$ reunião. $9^{\mathrm{a}}$ versão, 2017. p. 10.
} 
elaborados, de modo que sejam eficazes para todos os Estados, viabilizando a Convenção, apesar das diferentes culturas jurídicas envolvidas.

Esses parâmetros utilizados para a verificação da legitimidade da jurisdição internacional estão dispostos, como mencionado, no artigo $5^{\circ}$, o mais complexo do Projeto. Eles podem ser resumidos (de forma não exaustiva) em: (1) local do domicílio (habitual residence) da pessoa artigo 5.1(a); (2) local da filial, agência ou estabelecimento mantido pela pessoa jurídica - artigo 5.1(d); (3) submissão à jurisdição - artigo 5.1(c, e, f); (4) local do cumprimento da obrigação contratual - artigo 5.1(g) e (5) local da prática do ato danoso - artigo 5.1(j) ${ }^{84}$.

$\mathrm{O}$ artigo 5.1(a) traz a residência habitual (habitual residence) da pessoa contra quem é pedido o reconhecimento ou a execução como um dos requisitos que, se preenchido, tornará a sentença passível de reconhecimento ou execução. Essa residência habitual no Estado de origem, no momento em que a pessoa se tornou parte do processo na corte de origem, foi uma hipótese colocada no Projeto como forma de aproximar, nesse termo, as regras de jurisdição que já eram usadas e consequentemente aceitas pela maioria dos Estados, apesar de seus sistemas legais não usarem sempre a mesma denominação (essa regra também é encontrada em vários instrumentos internacionais). A escolha do termo habitual residence para essa Convenção (assim como para muitas outras) foi, de acordo com Bonomi, decorrente do fato de que nem todos os Estados Contratantes têm, em seus sistemas legais, a mesma definição de domicílio, o que poderia levar a um cenário em que cada país interpretaria esse conceito de forma diferente. O Projeto não oferece a definição de residência habitual da pessoa natural (diferentemente da residência habitual da pessoa jurídica,

\footnotetext{
${ }^{84}$ ARAUJO, Nadia de; NARDI, Marcelo de. Projeto de Sentenças Estrangeiras da Conferência de Haia: Por um Regime Global de Circulação Internacional de Sentenças em Matéria Civil e Comercial. Revista de Estudos Institucionais, Vol. 2, 2, 2016. p. 723.
} 
que é definida no artigo 3(2) do Projeto), mas há um entendimento geral de que seria o local onde está situado o principal centro de seus interesses ${ }^{85}$.

O inciso I do artigo 21 do CPC/2015 fala do foro do domicílio do réu como fato definidor da competência da autoridade judiciária brasileira (e o CPC/2015 também aponta para o foro do domicílio do réu como fundamento para determinar o foro de propositura da ação, por exemplo, como prevê o artigo $46^{86}$ ), enquanto o inciso I, alínea $a$, do artigo 22 , menciona o domicílio do credor.

$\mathrm{O}$ termo principal place of business, encontrado no artigo 5.1(b), foi incluído pensando nos prestadores de serviço em nome próprio, como no caso dos profissionais liberais, que poderiam ter seu domicílio em um Estado mas também prestar serviços em outro país, habitualmente ${ }^{87}$. Assim, o dispositivo determina que para que a sentença possa ser reconhecida ou executada, é preciso que a ação que lhe deu origem seja baseada nas atividades profissionais daquela pessoa contra quem se busca esse reconhecimento ou execução, e que seu principal estabelecimento profissional (principal place of business) fosse localizado no Estado de origem, no momento em que a pessoa se tornou parte na lide. A legislação brasileira se aproxima disso no artigo 21, inciso III do CPC/2015, que estipula a competência da autoridade judiciária brasileira quando $\mathrm{o}$ fundamento da ação for um fato ocorrido ou um ato praticado no Brasil.

$\mathrm{O}$ artigo 5.1(c) traz a hipótese da pessoa que ajuizou a ação da qual resultou a sentença ser aquela contra quem é pedido o reconhecimento ou a execução. Ao ajuizar a ação, a parte aceitou se submeter àquela jurisdição e, portanto, ela é considerada competente. A mesma regra é encontrada no CPC/2015 em seu artigo 22, inciso III:

\footnotetext{
${ }^{85}$ BONOMI, Andrea. Courage or Caution? A Critical Overview of the Hague Preliminary Draft on Judgments. Yearbook of Private International Law, Volume 17 (2015/2016). p. 13

${ }^{86}$ CPC2015, Lei 13.105/2015, vigência em 18 mar. 2016. Assim está redigido o art. 46:

"A ação fundada em direito pessoal ou em direito real sobre bens móveis será proposta, em regra, no foro de domicílio do réu. (...)."

${ }^{87}$ ARAUJO, Nadia de; MARCELO, Nardi de. POLIDO, Fabricio B. P. Reunião da próxima Comissão Especial da Conferência da Haia. Análise do Anteprojeto. Memória das negociações da $2^{\mathrm{a}}$ reunião. $9^{\mathrm{a}}$ versão, 2017. p. 12
} 
Art. 22. Compete, ainda, à autoridade judiciária brasileira processar e julgar as ações:

(...) III - em que as partes, expressa ou tacitamente, se submeterem à jurisdição nacional.

Outra hipótese de submissão à jurisdição está no artigo 5.1(e) e ocorre quando, no curso do processo que resultou na sentença em questão, o réu aceita expressamente a competência do juízo de origem. Considerandose que o dispositivo afirma que essa aceitação do réu deve ocorrer durante os procedimentos, o artigo não se aplicaria aos acordos de escolha de foro, já que nesse caso o consentimento para se submeter à jurisdição da corte eleita pelas partes é prévio. Bonomi expressa opinião contrária a essa restrição colocada pela redação do artigo 5.1(e), argumentando que já há previsão de invocação de acordo exclusivo de escolha de foro como fundamento para a recusa de um pedido de reconhecimento e execução (artigo 7.1(d) do Projeto) e a Convenção deve, então, garantir também o reconhecimento e a execução das sentenças proferidas pela corte selecionada no acordo. Além disso, nem todos os futuros Estados Contratantes da Convenção são também membros da Convenção sobre os Acordos de Eleição do Foro e, portanto, o fato desta Convenção de 2005 viabilizar o reconhecimento e a execução de sentenças pela corte escolhida pelas partes não significa que a Convenção sobre Sentenças não deva fazer o mesmo; pelo contrário, o fato da Convenção sobre os Acordos de Eleição do Foro estar em vigor em apenas alguns países é um forte motivo para que seja adicionada ao Projeto essa possibilidade. Ademais, apesar da Convenção sobre os Acordos de Eleição do Foro tratarem da circulação de sentenças proferidas com base em acordos exclusivos de eleição de foro, Bonomi sugere que o Projeto deveria ponderar a possibilidade de 
acrescentar também acordos não exclusivos de eleição de foro como mais uma base para reconhecimento e execução de sentenças estrangeiras ${ }^{88}$.

$\mathrm{O}$ artigo 5.1(f) traz mais uma hipótese de submissão à jurisdição mas, neste caso, realizada tacitamente, pois ocorre quando o réu comparece ao juízo de origem e não opõe uma exceção de incompetência (quando seria possível fazê-lo) ou seja, não questiona a jurisdição daquela corte. Ao não questioná-la, ele está aceitando-a, ainda que não o faça de forma expressa.

O local de filial, agência ou outro estabelecimento sem personalidade jurídica própria, pertencentes ao réu, ao tempo em que se tornou parte na lide, é apontado no artigo 5.1(d), juntamente com a necessidade da ação que deu origem à sentença ter relação com as atividades dessa filial, agência ou estabelecimento mantidos no Estado de origem. $\mathrm{O}$ artigo 21 do $\mathrm{CPC} / 2015$ traz a mesma regra, de forma ainda mais abrangente, no seu inciso I e parágrafo único.

Já o inciso II do artigo 21 do $\mathrm{CPC} / 2015$, encontra seu correspondente no artigo 5.1(g) do Projeto, que aponta uma vinculação para fins jurisdicionais quando a sentença versar sobre uma obrigação contratual e tiver sido proferida por uma corte do Estado em que essa obrigação foi ou deveria ter sido executada, seja por acordo entre as partes, seja devido à lei aplicável ao contrato, no caso de não haver determinação prévia sobre o direito aplicável; este caso da lei aplicável ao contrato não será válido, para os fins deste artigo, se as atividades do réu com relação à obrigação manifestamente não tenham vinculação intencional ou substancial com aquele Estado.

O artigo 5.1(h) traz o caso da sentença que trata de locação de bem imóvel e que tenha sido proferida no Estado onde está situado o imóvel. Esta disposição está em concordância com as regras de jurisdição exclusivas previstas no artigo 23 do CPC/2015. Daniela Vargas acrescenta que esse artigo possibilitaria a circulação de sentenças decorrentes de ações

\footnotetext{
${ }^{88}$ BONOMI, Andrea. Courage or Caution? A Critical Overview of the Hague Preliminary Draft on Judgments. In: Yearbook of Private International Law, Volume 17 (2015/2016). p. 16.
} 
relativas a contratos de locação por temporada, e que seria importante fazer uma distinção entre os contratos de médio-longo prazo e os de curto prazo $^{89}$.

O artigo 5.1(i) trata da sentença relativa à uma obrigação contratual garantida por um direito real imobiliário. Já no artigo 5.1(j), fala-se da sentença que diz respeito à uma obrigação não contratual decorrente de óbito, lesão corporal, dano material ou perda de bem tangível; para se estabelecer a vinculação com a jurisdição, a ação ou omissão causadora do dano precisa ter ocorrido no Estado de origem, não importando o local onde o dano se consumou. O artigo 21, inciso III do CPC/2015 é semelhante a este dispositivo do Projeto, apesar de mais abrangente, referindo-se apenas ao local do fato ou ato, sem mencionar as duas restrições apontadas no Projeto (tipo do dano e ação ou omissão que causou diretamente o dano).

O artigo 5.1(k), ainda em discussão, traz o caso da sentença que trata de violação de patente, marca, desenho, modelo, cultivares ou outro direito análogo sujeito a depósito ou registro, proferida por corte do Estado em que o depósito ou registro do direito em questão tenha sido feito ou em que se considere ter sido feito sob os termos de instrumento internacional ou regional.

O dispositivo seguinte, artigo 5.1(1), dispõe sobre o caso de sentença que diga respeito à titularidade ou existência de direitos autorais ou direitos conexos que sejam regidos pela lei do Estado de origem. Também menciona direitos de propriedade intelectual que não requeiram registro, mas, esta parte, assim como todo o artigo, ainda está em fase de negociações. Ainda haverá debates também em torno da alínea $m$, acerca de sentenças que versem sobre infrações de direito autoral ou direitos correlatos, tutelados pela lei do Estado de origem.

\footnotetext{
${ }^{89}$ ARAUJO, Nadia de; MARCELO, Nardi de. POLIDO, Fabricio B. P. Reunião da próxima Comissão Especial da Conferência da Haia. Análise do Anteprojeto. Memória das negociações da $2^{\mathrm{a}}$ reunião. $9^{\mathrm{a}}$ versão, 2017. p. 14.
} 
No artigo 5.1(n) vemos a hipótese concernente à sentença que gire em torno da validade, interpretação, efeitos, administração ou modificação de um trust constituído de forma voluntária e documentado por escrito. Para que ocorra a aceitação da jurisdição estrangeira é preciso que, no momento de instauração dos procedimentos, o ato constitutivo do trust tenha designado o Estado de origem da sentença como aquele no qual quaisquer disputas relativas àquelas questões seriam dirimidas. Se não for este o caso, a sentença ainda poderá ser aceita para fins de reconhecimento e execução, caso a lei do Estado de origem tenha sido indicada, expressa ou implicitamente, no ato constitutivo do trust, como sendo aquela que rege o elemento objeto da disputa da qual resultou a sentença. Uma terceira possibilidade seria o caso do Estado de origem ter sido designado no ato constitutivo do trust como o Estado onde se situa o local principal de administração do trust, podendo essa indicação ter sido feita de forma expressa ou implícita, no momento de instituição dos procedimentos. Ressalta-se, no entanto, que essa terceira possibilidade só se aplica às sentenças que tratam dos aspectos internos do trust entre pessoas que fazem parte ou faziam parte da relação com o trust.

Uma sentença que diga respeito a reconvenção será aceita para reconhecimento ou execução, como disposto na alínea $o$ do artigo 5.1. O dispositivo continua, deixando claro que isto ocorrerá (i) na medida em que a sentença seja favorável ao reconvinte e sob a condição de que a reconvenção seja em relação ao mesmo negócio ou aos mesmos fatos da ação principal; (ii) na medida em que a sentença seja contrária ao reconvinte, salvo se o ajuizamento de reconvenção for exigido pelo direito do Estado de origem, sob pena de preclusão.

Finalmente, o artigo 5.1(p) indica a hipótese de sentença que tenha sido proferida por uma corte designada em um acordo concluído ou documentado por escrito, ou por qualquer outro meio de comunicação que confira informações acessíveis para que possam ser usadas para referência subsequente, em vez de um acordo exclusivo de escolha de foro. Como 
aponta Marcelo de Nardi, o CPC/2015 criou um caso de competência exclusiva negativa da autoridade judiciária brasileira, quando seu artigo 25 dispõe que ela não será competente para processar e julgar ações que girem em torno de um contrato internacional no qual se encontre uma cláusula elegendo exclusivamente um foro estrangeiro para dirimir litígios decorrentes daquele contrato. $\mathrm{O}$ autor ressalta, ainda, que neste caso do artigo 25 do $\mathrm{CPC} / 2015$, as partes podem modificar a jurisdição, submetendo-se tacitamente a outra que não eleita anteriormente (artigos 25, $\S 2^{\mathrm{o}}$ e $63, \S \S 1^{\mathrm{o}}$ a $\left.4^{\mathrm{o}}, \mathrm{CPC} / 2015\right)^{90}$.

$\mathrm{O}$ artigo 5.2 acrescenta que as alíneas $f, g$ e $p$ do parágrafo anterior não serão aplicadas caso o reconhecimento ou a execução forem promovidos contra uma pessoa natural que tenha agido principalmente por motivos pessoais, familiares ou domésticos (um consumidor) em decorrência de relação contratual de consumo, ou contra um empregado por questões relativas a seu contrato de trabalho. Além disso, a alínea $e$ do artigo 5.1 só será aplicada se o consentimento do réu, do qual trata tal alínea, tiver sido manifestado perante a corte, oralmente ou por escrito. Esta limitação à aplicação do artigo 5.1(e) foi acrescentada, como destaca Marcelo de Nardi, porque o artigo 5.2 está tratando de hipossuficientes (consumidor e trabalhador) que, naturalmente, precisam de maior proteção. $\mathrm{O}$ autor ressalta também que as disposições desse artigo 5.2 só se referem a sentenças cujo reconhecimento ou execução são promovidos contra um consumidor ou trabalhador; se a sentença for a favor dessas pessoas, as regras gerais serão aplicadas.

Se o Estado requerido receber um pedido de reconhecimento e execução de uma sentença estrangeira na qual não se verifique a ocorrência de nenhuma das situações dispostas no artigo das bases indiretas de jurisdição e discutidas acima, o pedido poderá ser negado.

\footnotetext{
${ }^{90}$ ARAUJO, Nadia de; MARCELO, Nardi de. POLIDO, Fabricio B. P. Reunião da próxima Comissão Especial da Conferência da Haia. Análise do Anteprojeto. Memória das negociações da $2^{\mathrm{a}}$ reunião. $9^{\mathrm{a}}$ versão, 2017. p. 15
} 


\title{
4. Impactos da Convenção no Brasil
}

Como abordado no capítulo anterior, o Projeto da Convenção estabelece uma lista, em seu artigo $5^{\circ}$, com situações cuja ocorrência obrigará o Estado requerido, aquele que recebeu um pedido de reconhecimento e execução de sentença estrangeira, a admitir esta sentença $^{91}$. São as bases indiretas de jurisdição, extremamente importantes e essenciais para o funcionamento da Convenção.

Araujo, Polido e Nardi comentam que

\begin{abstract}
O valor de se estabelecerem bases indiretas de jurisdição em uma convenção internacional está na padronização das bases indiretas de jurisdição, resultando no efeito de que esse tema não será obstáculo à circulação da sentença estrangeira quando o juiz do país de origem exercer jurisdição com base nas regras descritas nos filtros jurisdicionais. ${ }^{92}$
\end{abstract}

Percebe-se, com isso, como a futura Convenção será benéfica ao Brasil, que atualmente recebe um grande número de sentenças estrangeiras, enquanto acredita-se serem as sentenças brasileiras recepcionadas por outros Estados com maiores dificuldades e em menor número.

Destacam os mesmos autores, em sua análise do artigo $5^{\circ}$, que algumas das hipóteses por ele previstas são mais restritas do que aquelas aceitas pela legislação brasileira, dispostas nos artigos 21 a 25 do $\mathrm{CPC} / 2015$. Isso significa, portanto, que o número de sentenças brasileiras enviadas e homologadas em outros Estados provavelmente ainda será menor do que o número de sentenças estrangeiras recebidas e homologadas pelo Brasil; isto porque, com as limitações estabelecidas pelo artigo do Projeto sendo mais restritivas, uma sentença proferida de acordo com as normas de jurisdição brasileiras, mais abrangentes, nem sempre se

\footnotetext{
${ }^{91}$ ARAUJO, Nadia de; NARDI, Marcelo de. Projeto de Sentenças Estrangeiras da Conferência de Haia: Por um Regime Global de Circulação Internacional de Sentenças em Matéria Civil e Comercial. Revista de Estudos Institucionais, Vol. 2, 2, 2016. p. 724.

${ }^{92}$ ARAUJO, Nadia de; POLIDO, Fabrício Bertini Pasquot; NARDI, Marcelo de. A Conferência da Haia e o Reconhecimento e Execução de Sentenças Estrangeiras: primeiras impressões sobre o projeto em negociação. 2016. p. 8.
} 
enquadrará também nas regras indicadas pelo artigo $5^{\circ}$. Não obstante, como mencionado acima, a Convenção certamente influenciará em um aumento na quantidade de sentenças brasileiras sendo executadas em outros países, configurando, portanto, um avanço muito positivo e almejado pelo Brasil.

$\mathrm{O}$ fato de serem estabelecidas essas bases indiretas de jurisdição também provocará consequências para a atuação do STJ ao receber um pedido de homologação pois o órgão, diferentemente do que ocorre atualmente, terá que realizar um controle mais profundo da jurisdição da autoridade estrangeira ${ }^{93}$. Compreende-se, então, que o ingresso do Brasil nesta Convenção não só contribuirá para uma maior circulação de sentenças proferidas por autoridade judiciária brasileira, como também vai fazer com que o Brasil tenha uma posição mais exigente e restritiva no que tange ao recebimento das sentenças estrangeiras.

Como apontam Araujo e Nardi, "os filtros jurisdicionais aumentam o escrutínio sobre a vinculação com o caso concreto da jurisdição do Estado requerente" 94 e, assim, para facilitar a circulação das sentenças sob as regras da Convenção, a autoridade judiciária brasileira que proferir uma sentença com prospectiva eficácia em outro Estado deverá se preocupar em demonstrar quais foram os critérios utilizados para se admitir a jurisdição nacional naquele caso ${ }^{95}$.

Em suma, a Convenção possibilitará que a autoridade judiciária brasileira (assim como as autoridades judiciárias de todos os Estados Contratantes) tenha maior facilidade em proferir sentenças que sejam facilmente reconhecidas e executadas em outros Estados, uma vez que todas as regras que devem ser observadas para garantir essa circulação, assim

\footnotetext{
93 ARAUJO, Nadia de; MARCELO, Nardi de. POLIDO, Fabricio B. P. Reunião da próxima Comissão Especial da Conferência da Haia. Análise do Anteprojeto. Memória das negociações da $2^{\mathrm{a}}$ reunião. $9^{\mathrm{a}}$ versão, 2017. p. 11.

${ }^{94}$ ARAUJO, Nadia de; NARDI, Marcelo de. Projeto de Sentenças Estrangeiras da Conferência de Haia: Por um Regime Global de Circulação Internacional de Sentenças em Matéria Civil e Comercial. In: Revista de Estudos Institucionais, Vol. 2, 2, 2016. p. 723

${ }^{95}$ Ibid. p. 723
} 
como as regras utilizadas para o controle indireto de jurisdição, estarão disponíveis na própria Convenção. 


\section{Conclusão}

O Código de Processo Civil de 2015, abordado no capítulo 1 deste trabalho, foi responsável por trazer muitas inovações ao ordenamento jurídico brasileiro, no que tange à jurisdição internacional e à cooperação jurídica internacional. Foi analisado anteriormente como muitos de seus artigos relacionados à esta temática estão em harmonia com as disposições do Projeto de Convenção.

Além das já apontadas semelhanças, pode ser citado também como exemplo o artigo 961 do $\mathrm{CPC} / 2015$ que, em seu $\S 1^{\circ}$, dispõe que não apenas a decisão judicial definitiva poderá ser homologada, como também poderá o ser a decisão não judicial que teria natureza jurisdicional (no caso, natureza de sentença), de acordo com a lei brasileira. Sobre essa questão, vimos que o artigo $3^{\circ}$ do Projeto de 2017 estabelece o mesmo:

\section{Article 3 \\ Definitions}

1. In this Convention -

(...) (b) "judgment" means any decision on the merits given by a court, whatever that decision may be called, including a decree or order, and a determination of costs or expenses by the court (including an officer of the court), provided that the determination relates to a decision on the merits which may be recognised or enforced under this Convention. An interim measure of protection is not a judgment. $(\ldots)^{96}$.

$\mathrm{O} \S 2^{\circ}$ do artigo 961 do $\mathrm{CPC} / 2015$, por sua vez, também encontra correspondência no Projeto, ao explicitar que existe a possibilidade de homologação parcial de sentença estrangeira. O artigo $10^{\circ}$ do Projeto estabelece:

\footnotetext{
${ }^{96}$ Tradução livre da autora:

1. Nesta Convenção -

(...) (b) "sentença" significa qualquer decisão de mérito proferida por uma corte, independentemente de como a decisão for chamada, inclusive um decreto ou ordem, e uma determinação de custas ou despesas pelo tribunal (incluindo um oficial do tribunal), desde que a determinação se refira à uma decisão de mérito que possa ser reconhecida ou executada sob esta Convenção. Uma tutela provisória de proteção não é uma sentença. (...)
} 
Article 10

Severability

Recognition or enforcement of a severable part of a judgment shall be granted where recognition or enforcement of that part is applied for, or only part of the judgment is capable of being recognised or enforced under this Convention ${ }^{97}$.

Como também já mencionado, outro grande avanço do CPC/2015 foi impor uma limitação à competência da autoridade judiciária brasileira para processar e julgar ações nos casos em que houver uma cláusula contratual de eleição de foro estrangeiro. Deste modo, o ordenamento jurídico brasileiro está reconhecendo efetivamente e expressamente a vontade das partes e seu direito de escolher o foro onde desejam que os conflitos decorrentes de suas relações sejam dirimidos, em concordância com a Convenção sobre os Acordos de Eleição de Foro de 2005.

Como discutido anteriormente, o STJ tem, até o momento, mantido o entendimento de que uma cláusula contratual de eleição de foro é válida, mas, ainda assim, se tratando de um caso de competência concorrente, não é afastada a competência da autoridade judiciária brasileira para processar e julgar ação sobre a mesma questão. A partir do discutido acima, entende-se ser imprescindível que o STJ modifique seu posicionamento para se adequar ao que é expressamente disposto pelo artigo 25 do CPC/2015.

Percebe-se então, com a análise das mudanças apresentadas pelo CPC/2015, que o ordenamento brasileiro está cada vez mais preparado e próximo do que será modificado no cenário internacional, com a entrada em vigor da Convenção.

As bases indiretas de jurisdição, dispostas no artigo $5^{\circ}$ do Projeto, são essenciais e fundamentais para a Convenção. Elas possibilitam que todos os Estados Contratantes tenham ciência de quais serão as regras a serem aplicadas no momento de se analisar um pedido de reconhecimento e execução de sentenças estrangeiras e, ainda mais importante, garantem que

\footnotetext{
${ }^{97}$ Tradução livre da autora: O reconhecimento ou a execução de uma parte separável de uma sentença deve ser concedido quando é solicitado o reconhecimento ou a execução dessa parte, ou apenas parte da sentença for capaz de ser reconhecida ou executada sob esta Convenção.
} 
as mesmas regras serão aplicadas pelas autoridades judiciárias de todos esses Estados, resultando em uma verdadeira uniformização legal.

Para o Brasil, essa Convenção sobre Reconhecimento e Execução de Sentenças Estrangeiras será, como já destacado, um grande e almejado avanço. Neste sentido, Araujo, Polido e Nardi destacam que

Para o Brasil, a conclusão e adoção generalizada da nova convenção representaria algo extremamente desejável: as decisões brasileiras poderão circular com maior facilidade em escala global, pois esse é o alcance uniformizador dado pela Conferência da Haia ao instrumento ambicionado ${ }^{98}$.

Além disso, com a entrada em vigor da Convenção, será necessário que o STJ passe a realizar uma análise mais profunda das sentenças estrangeiras cujo reconhecimento e execução são pedidos, utilizando-se dos critérios estabelecidos pelas bases indiretas de jurisdição.

Como apontam os autores citados acima, "a adoção desse novo sistema pode inspirar alterações nos critérios brasileiros de reconhecimento de sentenças estrangeiras, com reflexos positivos e construtivos à nova sistemática processual brasileira" ${ }^{99}$.

Acredita-se que, com a observação das bases indiretas de jurisdição, será possibilitada a realização dos objetivos pretendidos com a Convenção. $\mathrm{O}$ fato das partes de um contrato terem a autonomia da vontade para determinarem em que foro desejam que seus conflitos sejam resolvidos, através da inclusão de uma cláusula de eleição de foro em seu contrato, que será respeitada pelas autoridades judiciárias, já traz aquela segurança jurídica que há muito era buscada.

Ademais, a possibilidade de se saber previamente qual será a lei aplicada pelos tribunais e quais são os requisitos que devem ser observados para que uma sentença estrangeira seja reconhecível e executável - assim como a certeza de que a sentença será reconhecida e executada, estando

\footnotetext{
${ }^{98}$ ARAUJO, Nadia de; POLIDO, Fabrício Bertini Pasquot; NARDI, Marcelo de. A Conferência da Haia e o Reconhecimento e Execução de Sentenças Estrangeiras: primeiras impressões sobre o projeto em negociação. 2016. p. 23.

${ }^{99}$ Ibid.
} 
presente alguma das hipóteses elencadas no artigo das bases indiretas de jurisdição - não só contribui para reforçar a segurança jurídica como também, consequentemente, auxilia as partes a fazerem escolhas informadas e reduzirem seus custos no momento de propor ações perante uma corte.

Todas essas circunstâncias agregadas pela Convenção que permitem uma circulação mais facilitada de sentenças estrangeiras, enviadas de um Estado Contratante para outro, também promovem os dois objetivos principais da Conferência da Haia de Direito Internacional Privado ao decidir criar esta Convenção: contribuem para melhorar o acesso à justiça, assim como para a realização de negócios e transações internacionais de forma menos complexa, devido à diminuição de riscos e custos dessas relações transfronteiriças, complementando ainda os esforços nesse sentido feitos pela Convenção sobre os Acordos de Eleição de Foro ${ }^{100}$.

Finalmente, com a entrada em vigor da Convenção, todos os Estados Contratantes, ao receberem um pedido de reconhecimento e execução de sentença estrangeira, assim como todas as autoridades judiciárias, ao proferirem uma sentença que desejam seja futuramente reconhecida e executada em outro Estado Contratante, aplicarão esse conjunto uniforme de regras disposto pela Convenção, culminando-se na configuração de uma verdadeira e efetiva cooperação jurídica internacional ${ }^{101}$.

\footnotetext{
${ }^{100}$ Record of Introductory Remarks of the Chair of the Special Commission (1-9 June 2016). Haia: Conferência da Haia de Direito Internacional Privado, 2017.

${ }^{101}$ ARAUJO, Nadia de; NARDI, Marcelo de. Projeto de Sentenças Estrangeiras da Conferência de Haia: Por um Regime Global de Circulação Internacional de Sentenças em Matéria Civil e Comercial. Revista de Estudos Institucionais, Vol. 2, 2, 2016. Pág. 733
} 


\section{Bibliografia}

A Conferência da Haia de Direito Internacional Privado. Disponível em: $<$ https://www.hcch.net/pt/about/>. Acesso em 05 mar. 2017.

ARAUJO, Nadia de. Direito Internacional Privado: Teoria e Prática

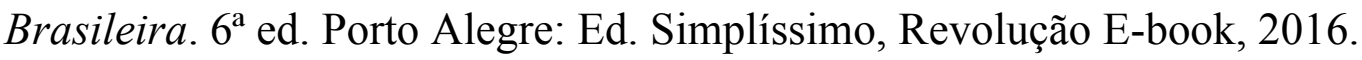

ARAUJO, Nadia de; MARCELO, Nardi de. POLIDO, Fabricio B. P. Reunião da próxima Comissão Especial da Conferência da Haia. Análise do Anteprojeto. Memória das negociações da 2a reunião. 9ª versão, 2017.

ARAUJO, Nadia de; NARDI, Marcelo de. Projeto de Sentenças Estrangeiras da Conferência de Haia: Por um Regime Global de Circulação Internacional de Sentenças em Matéria Civil e Comercial. In: Revista de Estudos Institucionais, Vol. 2, 2, 2016.

ARAUJO, Nadia de; POLIDO, Fabrício Bertini Pasquot; NARDI, Marcelo de. A Conferência da Haia e o Reconhecimento e Execução de Sentenças Estrangeiras: primeiras impressões sobre o projeto em negociação. 2016.

Atribuições do STJ. Disponível em: <http://www.stj.jus.br/sites/STJ/default/pt_BR/Institucional/Atribuições>. Acesso em: 07 mar. 2017.

BEAUMONT, Paul; WALKER, Lara. Recognition and enforcement of judgments in civil and commercial matters in the Brussels I Recast and some lessons from it and the recent Hague Conventions for the Hague Judgments Project. In: The Journal of Private International Law, 2015, Vol. 11, Issue 1, p. 31-63.

BONOMI, Andrea. Courage or Caution? A Critical Overview of the Hague Preliminary Draft on Judgments. In: Yearbook of Private International Law, Volume 17, 2015/2016. 
BRAND, Ronald. The Continuing Evolution of US Judgments Recognition Law. Legal Studies Research Paper Series Working Paper No. 2015-37. University of Pittsburgh School of Law, 2015.

Carta do Departamento de Estado dos Estados Unidos disponível em: $<$ https://www.state.gov/documents/organization/65973.pdf $>$. Acesso em: 11 mar. 2017.

Código de Processo Civil de 2015. Disponível em: $<$ http://www.planalto.gov.br/ccivil_03/_ato20152018/2015/lei/113105.htm>. Acesso em 23 fev. 2017.

Comissão Especial sobre Reconhecimento e Execução de Sentenças Estrangeiras. 2016 Preliminary Draft Convention. Haia: Conferência da Haia sobre Direito Internacional Privado, 2016. Disponível em: $<$ https://assets.hcch.net/docs/42a96b27-11 fa-49f9-8e48-a82245aff1a6.pdf $>$. Acesso em: 20 mar. 2017.

Constituição da República Federativa do Brasil de 1988. Disponível em: $<$ http://www.planalto.gov.br/ccivil_03/constituicao/constituicaocompilado. htm>. Acesso em: 11 mar. 2017.

Constituição dos Estados Unidos. Disponível em: $<$ https://www.senate.gov/civics/constitution_item/constitution.htm\#amend ments>. Acesso em: 14 abr. 2017.

Convenção sobre os Acordos de Eleição de Foro. Disponível em: $<$ https:/www.hcch.net/pt/instruments/conventions/full-text/?cid=98>. Acesso em: 02 mar. 2017.

Council on General Affairs and Policy of the Conference (15-17 March 2016). Conclusions and Recommendations adopted by the Council. Haia: Conferência da Haia sobre Direito Internacional Privado, 2016. p. 2. 
Disponível em: <https://assets.hcch.net/docs/679bd42c-f974-461a-8e1a31e1b51eda10.pdf $>$. Acesso em: 20 mar. 2017.

Estatuto da Conferência da Haia de Direito Internacional Privado. Disponível em: $<$ https://www.hcch.net/pt/instruments/conventions/fulltext>. Acesso em 05 mar. 2017.

Grupo de Pesquisa do Prof. José Miguel Garcia Medina. Quadro comparativo entre o CPC/1973 e o CPC/2015, $2^{\mathrm{a}}$ versão, 2015. Disponível em: $\quad<\mathrm{http}: / /$ boletimjuridico.publicacoesonline.com.br/wpcontent/uploads/2015/03/Quadro-comparativo-CPC-1973-x-CPC2015.pdf>. Acesso em 09 mar. 2017.

Informações acerca da Convenção sobre os Acordos de Eleição de Foro. Disponíveis em:

$<$ https://www.hcch.net/pt/instruments/conventions/specialisedsections/choice-of-court>. Acesso em: 02 mar. 2017.

Informações sobre o Judgments Project. Disponíveis em: $<$ https://www.hcch.net/pt/projects/legislative-projects/judgments/>. Acesso em: 12 mar. 2017.

Lei de Introdução às normas do Direito Brasileiro. Disponível em: $<$ http://www.planalto.gov.br/ccivil_03/decretolei/Del4657compilado.htm>. Acesso em: 24 fev. 2017.

MANTOVANI, Denise. Há litispendência entre uma ação ajuizada no Brasil e outra no Estrangeiro? Disponível em: $<$ https://lfg.jusbrasil.com.br/noticias/93291/ha-litispendencia-entre-umaacao-ajuizada-no-brasil-e-outra-no-estrangeiro-denise-mantovani>. Acesso em: 18 mai. 2017. 
Mapa dos sistemas jurídicos utilizados no mundo disponível em: $<$ https://www.law.berkeley.edu/library/robbins/pdf/CommonLawCivilLaw Traditions.pdf>. Acesso em: 28 mai. 2017.

Overview of the Judgments Project. Haia: Conferência da Haia sobre Direito Internacional Privado. Disponível em: $<$ https://assets.hcch.net/docs/905df382-c6e0-427b-a5e9-

b8cfc471b575.pdf>. Acesso em: 16 abr. 2017.

Permanent Bureau. Glossary of Commonly Used Terms and References. Haia: Conferência da Haia sobre Direito Internacional Privado, 2016. Disponível em: <https://assets.hcch.net/docs/2d15f975-623c-4a29-b972164862a91866.pdf>. Acesso em: 18 mai. 2017.

POJANOWSKI, Jeffrey A. Reading Statutes in the Common Law Tradition. In: Virginia Law Review, Volume 101, issue 5, Va. L. Rev. 1357, 2015. Disponível

em:

$<$ http://www.virginialawreview.org/volumes/content/reading-statutescommon-law-tradition>. Acesso em: 30 mai. 2017.

POTSCH, Julia; DAPIEVE, Marianna; ALMEIDA, Renato de. Cooperação Jurídica Internacional: o Projeto sobre Reconhecimento e Execução de Sentenças da Conferência da Haia de Direito Internacional Privado. Rio de Janeiro. 2016. 20p. Pibic - Departamento de Direito da PUC-Rio.

Record of Introductory Remarks of the Chair of the Special Commission (19 June 2016). Haia: Conferência da Haia de Direito Internacional Privado, 2017. Versão disponível apenas para delegados, cópia com a autora.

Resolução $\mathrm{n}^{\mathrm{o}}$ 9/2005 do STJ. Disponível em: $<$ http://www.stj.jus.br/SCON/legislacao/doc.jsp?livre=cartas + rogat\%F3rias $\& \& b=$ LEGI $\& p=$ true $\& \mathrm{t}=\& \mathrm{l}=20 \& \mathrm{i}=1>$. Acesso em: 10 mar. 2017. 
Special Commission on the Recognition and Enforcement of Foreign Judgments (16-24 February 2017). Haia: Conferência da Haia sobre Direito Internacional Privado, $2017 . \quad$ Disponível em: $<$ https://assets.hcch.net/docs/d6f58225-0427-4a65-8f8b180e79cafdbb.pdf $>$. Acesso em: 08 mar. 2017.

STJ, Corte Especial, AgRg na Sentença Estrangeira $n^{0} 456$ - JP (2005/0006914-6), Rel. Min. Barros Monteiro, Brasília, j. 23 nov. 2006, DJ 05 fev. 2007 p. 171.

STJ, Corte Especial, SEC no 11.429 - EX (2014/0271818-3), Rel. Min. Napoleão Nunes Maia Filho, Brasília, j. 03 jun. 2015, DJe 04 ago. 2015.

STJ, Corte Especial, SEC no 12.897 - EX (2014/0301071-1), Rel. Min. Raul Araújo, Brasília, j. 16 dez. 2015, DJe 02 fev. 2016.

STJ, Corte Especial, SEC n ${ }^{\circ} 14.518$ - EX (2015/0234206-0), Rel. Min. Og Fernandes, Brasília, j. 29 mar. 2017, DJe 05 abr. 2017.

STJ, Corte Especial, SEC no 15.004 - EX (2015/0310499-3), Rel. Min. Nancy Andrighi, Brasília, j. 15 fev. 2017, DJe 24 fev. 2017.

STJ, Corte Especial, SEC n ${ }^{0} 5.477$ - EX (2010/0095497-2), Rel. Min. Napoleão Nunes Maia Filho, Brasília, j. 06 mai. 2015, DJe 25 mai. 2015.

STJ, Quarta Turma, AgRg no Agravo em Recurso Especial nº 679.421 - RJ (2015/0060238-5), Rel. Min. Marco Buzzi, Brasília, j. 17 mar. 2016, DJe 31 mar. 2016.

STJ, Quarta Turma, Recurso Ordinário no 114 - DF (2011/0027483-8), Rel. Min. Raul Araújo, Brasília, j. 02 jun. 2015, DJe 25 jun. 2015.

STJ, Terceira Turma, Recurso Especial no 242.383 - SP (1999/0115183-0), Rel. Min. Humberto Gomes de Barros, Brasília, j. 03 fev. 2005, DJ 21 mar. 2005 p. 360. 
The Common Law and Civil Law Traditions. The Regents of the University of California, The Robbins Religious and Civil Law Collection, School of Law (Boalt Hall), University of California at Berkeley. Disponível em: $<$ https://www.law.berkeley.edu/library/robbins/CommonLawCivilLawTrad itions.html>. Acesso em: 28 mai. 2017. 
Special Commission on the Recognition and Enforcement of Foreign J udgments (16-24 February 2017)

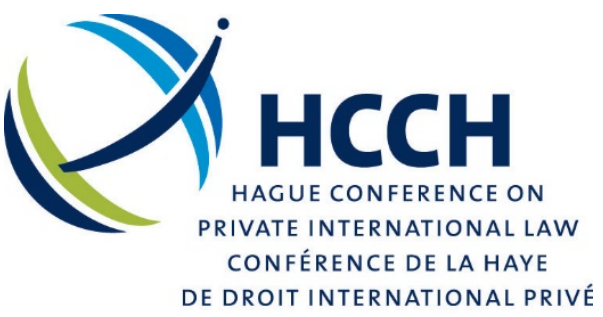

FEBRUARY 2017 DRAFT CONVENTI ON*

*This document reproduces the text set out in Working Document No $170 \mathrm{E}$ revised 


\section{CHAPTER I - SCOPE AND DEFINITIONS}

\section{Article 1}

Scope

1. This Convention shall apply to the recognition and enforcement of judgments relating to civil or commercial matters. It shall not extend in particular to revenue, customs or administrative matters.

2. This Convention shall apply to the recognition and enforcement in one Contracting State of a judgment given by a court of another Contracting State.

Article 2

Exclusions from scope

1. This Convention shall not apply to the following matters -

(a) the status and legal capacity of natural persons;

(b) maintenance obligations;

(c) other family law matters, including matrimonial property regimes and other rights or obligations arising out of marriage or similar relationships;

(d) wills and succession;

(e) insolvency, composition, resolution of financial institutions, and analogous matters;

(f) the carriage of passengers and goods;

(g) marine pollution, limitation of liability for maritime claims, general average, and emergency towage and salvage;

(h) liability for nuclear damage;

(i) the validity, nullity, or dissolution of legal persons or associations of natural or legal persons, and the validity of decisions of their organs;

(j) the validity of entries in public registers;

(k) defamation [and privacy];

[(I) intellectual property rights[, except for copyright and related rights and registered and unregistered trademarks]].

2. A judgment is not excluded from the scope of this Convention where a matter to which this Convention does not apply arose merely as a preliminary question in the proceedings in which the judgment was given, and not as an object of the proceedings. In particular, the mere fact that such a matter arose by way of defence does not exclude a judgment from the Convention, if that matter was not an object of the proceedings.

3. This Convention shall not apply to arbitration and related proceedings.

4. A judgment is not excluded from the scope of this Convention by the mere fact that a State, including a government, a governmental agency or any person acting for a State, was a party to the proceedings.

5. Nothing in this Convention shall affect privileges and immunities of States or of international organisations, in respect of themselves and of their property. 
Article 3

Definitions

1. In this Convention -

(a) "defendant" means a person against whom the claim or counterclaim was brought in the State of origin;

(b) "judgment" means any decision on the merits given by a court, whatever that decision may be called, including a decree or order, and a determination of costs or expenses by the court (including an officer of the court), provided that the determination relates to a decision on the merits which may be recognised or enforced under this Convention. An interim measure of protection is not a judgment.

2. An entity or person other than a natural person shall be considered to be habitually resident in the State -

(a) where it has its statutory seat;

(b) under whose law it was incorporated or formed;

(c) where it has its central administration; or

(d) where it has its principal place of business.

\section{CHAPTER II - RECOGNITION AND ENFORCEMENT}

Article 4

General provisions

1. A judgment given by a court of a Contracting State (State of origin) shall be recognised and enforced in another Contracting State (requested State) in accordance with the provisions of this Chapter. Recognition or enforcement may be refused only on the grounds specified in this Convention.

2. Without prejudice to such review as is necessary for the application of the provisions of this Chapter, there shall be no review of the merits of the judgment given by the court of origin.

3. A judgment shall be recognised only if it has effect in the State of origin, and shall be enforced only if it is enforceable in the State of origin.

4. If a judgment referred to in paragraph 3 is the subject of review in the State of origin or if the time limit for seeking ordinary review has not expired, the court addressed may -

(a) grant recognition or enforcement, which enforcement may be made subject to the provision of such security as it shall determine;

(b) postpone the decision on recognition or enforcement; or

(c) refuse recognition or enforcement.

A refusal under sub-paragraph (c) does not prevent a subsequent application for recognition or enforcement of the judgment.

Article 5

Bases for recognition and enforcement

1. A judgment is eligible for recognition and enforcement if one of the following requirements is met -

(a) the person against whom recognition or enforcement is sought was habitually resident in the State of origin at the time that person became a party to the proceedings in the court of origin; 
(b) the natural person against whom recognition or enforcement is sought had his or her principal place of business in the State of origin at the time that person became a party to the proceedings in the court of origin and the claim on which the judgment is based arose out of the activities of that business;

(c) the person against whom recognition or enforcement is sought is the person that brought the claim, other than a counterclaim, on which the judgment is based;

(d) the defendant maintained a branch, agency, or other establishment without separate legal personality in the State of origin at the time that person became a party to the proceedings in the court of origin, and the claim on which the judgment is based arose out of the activities of that branch, agency, or establishment;

(e) the defendant expressly consented to the jurisdiction of the court of origin in the course of the proceedings in which the judgment was given;

(f) the defendant argued on the merits before the court of origin without contesting jurisdiction within the timeframe provided in the law of the State of origin, unless it is evident that an objection to jurisdiction or to the exercise of jurisdiction would not have succeeded under that law;

(g) the judgment ruled on a contractual obligation and it was given in the State in which performance of that obligation took place, or should have taken place, in accordance with

(i) the parties' agreement, or

(ii) the law applicable to the contract, in the absence of an agreed place of performance, unless the defendant's activities in relation to the transaction clearly did not constitute a purposeful and substantial connection to that State;

(h) the judgment ruled on a tenancy of immovable property and it was given in the State in which the property is situated;

(i) the judgment ruled against the defendant on a contractual obligation secured by a right in rem in immovable property located in the State of origin, if the contractual claim was brought together with a claim against the same defendant relating to that right in rem;

(j) the judgment ruled on a non-contractual obligation arising from death, physical injury, damage to or loss of tangible property, and the act or omission directly causing such harm occurred in the State of origin, irrespective of where that harm occurred;

[ $(\mathrm{k})$ the judgment ruled on an infringement of a patent, trademark, industrial design, plant breeder's right, or similar right required to be granted or registered and it was given by a court in the State of origin in which the grant or registration of the right concerned has taken place, or is deemed to have taken place under the terms of an international or regional instrument[, unless the defendant has not acted in that State to initiate or further the infringement, or their activity cannot reasonably be seen as having been targeted at that State]; ]

[(I) the judgment ruled on the ownership or subsistence of copyright or related rights, [or use-based trademarks, trade names, or unregistered designs] [or other intellectual property rights not required to be registered] and the right is governed by the law of the State of origin; ]

$[(\mathrm{m})$ the judgment ruled on an infringement of copyright or related rights, [or use-based trademarks, trade names, or unregistered designs] [or other intellectual property rights not required to be registered] and the right is governed by the law of the State of origin, [unless the defendant has not acted in that State to initiate or further the infringement, or their activity cannot reasonably be seen as having been targeted at that State]; ]

(n) the judgment concerns the validity, construction, effects, administration or variation of a trust created voluntarily and evidenced in writing, and -

(i) at the time the proceedings were instituted, the State of origin was designated in the trust instrument as a State in which disputes about such matters are to be determined; 
(ii) the law of the State of origin is expressly or impliedly designated in the trust instrument as the law governing the aspect of the trust that is the subject of the litigation that gave rise to the judgment[, unless the defendant's activities in relation to the trust clearly did not constitute a purposeful and substantial connection to that State]; or

(iii) at the time the proceedings were instituted, the State of origin was expressly or impliedly designated in the trust instrument as the State in which the principal place of administration of the trust is situated.

This sub-paragraph only applies to judgments regarding internal aspects of a trust between persons who are or were within the trust relationship;

(o) the judgment ruled on a counterclaim -

(i) to the extent that it was in favour of the counterclaimant, provided that the counterclaim arose out of the same transaction or occurrence as the claim;

(ii) to the extent that it was against the counterclaimant, unless the law of the State of origin required the counterclaim to be filed in order to avoid preclusion;

(p) the judgment was given by a court designated in an agreement concluded or documented in writing or by any other means of communication which renders information accessible so as to be usable for subsequent reference, other than an exclusive choice of court agreement.

For the purposes of this sub-paragraph, an "exclusive choice of court agreement" means an agreement concluded by two or more parties that designates, for the purpose of deciding disputes which have arisen or may arise in connection with a particular legal relationship, the courts of one State or one or more specific courts of one State to the exclusion of the jurisdiction of any other courts.

2. If recognition or enforcement is sought against a natural person acting primarily for personal, family or household purposes (a consumer) in matters relating to a consumer contract, or against an employee in matters relating to the employee's contract of employment -

(a) paragraph $1(\mathrm{e})$ applies only if the consent was addressed to the court, orally or in writing;

(b) paragraph 1 (f), (g) and (p) do not apply.

Article 6

Exclusive bases for recognition and enforcement

Notwithstanding Article 5 -

[(a) a judgment that ruled on the registration or validity of a patent, trademark, industrial design, plant breeder's right, or similar right required to be granted or registered shall be recognised and enforced if and only if the State of origin is the State in which grant or registration has been applied for, has taken place, or is deemed to have been applied for or to have taken place under the terms of an international or regional instrument; ]

(b) a judgment that ruled on rights in rem in immovable property shall be recognised and enforced if and only if the property is situated in the State of origin;

(c) a judgment that ruled on a tenancy of immovable property for a period of more than six months shall not be recognised and enforced if the property is not situated in the State of origin and the courts of the Contracting State in which it is situated have exclusive jurisdiction under the law of that State. 
Article 7

Refusal of recognition or enforcement

1. Recognition or enforcement may be refused if -

(a) the document which instituted the proceedings or an equivalent document, including a statement of the essential elements of the claim -

(i) was not notified to the defendant in sufficient time and in such a way as to enable him to arrange for his defence, unless the defendant entered an appearance and presented his case without contesting notification in the court of origin, provided that the law of the State of origin permitted notification to be contested; or

(ii) was notified to the defendant in the requested State in a manner that is incompatible with fundamental principles of the requested State concerning service of documents;

(b) the judgment was obtained by fraud;

(c) recognition or enforcement would be manifestly incompatible with the public policy of the requested State, including situations where the specific proceedings leading to the judgment were incompatible with fundamental principles of procedural fairness of that State [and situations involving infringements of security or sovereignty of that State];

(d) the proceedings in the court of origin were contrary to an agreement, or a designation in a trust instrument, under which the dispute in question was to be determined in a court other than the court of origin;

(e) the judgment is inconsistent with a judgment given in the requested State in a dispute between the same parties; or

(f) the judgment is inconsistent with an earlier judgment given in another State between the same parties on the same subject matter, provided that the earlier judgment fulfills the conditions necessary for its recognition in the requested State;

[(g) the judgment ruled on an infringement of an intellectual property right, applying to that right a law other than the law governing that right. ]

2. Recognition or enforcement may be postponed or refused if proceedings between the same parties on the same subject matter are pending before a court of the requested State, where -

(a) the court of the requested State was seised before the court of origin; and

(b) there is a close connection between the dispute and the requested State.

A refusal under this paragraph does not prevent a subsequent application for recognition or enforcement of the judgment.

Article 8

Preliminary questions

1. Where a matter to which this Convention does not apply, or a matter referred to in Article 6 on which a court other than the court referred to in that Article ruled arose as a preliminary question, the ruling on that question shall not be recognised or enforced under this Convention.

2. Recognition or enforcement of a judgment may be refused if, and to the extent that, the judgment was based on a ruling on a matter to which this Convention does not apply, or on a matter referred to in Article 6 on which a court other than the court referred to in that Article ruled. 
3. However, in the case of a ruling on the validity of a right referred to in Article 6, paragraph (a), recognition or enforcement of a judgment may be postponed, or refused under the preceding paragraph, only where -

(a) that ruling is inconsistent with a judgment or a decision of a competent authority on that matter given in the State referred to in Article 6, paragraph (a); or

(b) proceedings concerning the validity of that right are pending in that State.

A refusal under sub-paragraph (b) does not prevent a subsequent application for recognition or enforcement of the judgment.

Article 9

Equivalent effects

A judgment recognised or enforceable under this Convention shall be given the same effect it has in the State of origin. If the judgment provides for relief that is not available under the law of the requested State, that relief shall, to the extent possible, be adapted to relief with effects equivalent to, but not going beyond, its effects under the law of the State of origin.

Article 10

Severability

Recognition or enforcement of a severable part of a judgment shall be granted where recognition or enforcement of that part is applied for, or only part of the judgment is capable of being recognised or enforced under this Convention.

Article 11

Damages

1. Recognition or enforcement of a judgment may be refused if, and to the extent that, the judgment awards damages, including exemplary or punitive damages, that do not compensate a party for actual loss or harm suffered.

2. The court addressed shall take into account whether and to what extent the damages awarded by the court of origin serve to cover costs and expenses relating to the proceedings.

[Article 12

Non-monetary remedies in intellectual property matters

A judgment granting a remedy other than monetary damages in intellectual property matters shall not be enforced under this Convention.]

Article 13

Judicial settlements (transactions judiciaires)

Judicial settlements (transactions judiciaires) which a court of a Contracting State has approved, or which have been concluded in the course of proceedings before a court of a Contracting State, and which are enforceable in the same manner as a judgment in the State of origin, shall be enforced under this Convention in the same manner as a judgment[, provided that such settlement is permissible under the law of the requested State]. 
Article 14

Documents to be produced

1. The party seeking recognition or applying for enforcement shall produce -

(a) a complete and certified copy of the judgment;

(b) if the judgment was given by default, the original or a certified copy of a document establishing that the document which instituted the proceedings or an equivalent document was notified to the defaulting party;

(c) any documents necessary to establish that the judgment has effect or, where applicable, is enforceable in the State of origin;

(d) in the case referred to in Article 13, a certificate of a court of the State of origin that the judicial settlement or a part of it is enforceable in the same manner as a judgment in the State of origin.

2. If the terms of the judgment do not permit the court addressed to verify whether the conditions of this Chapter have been complied with, that court may require any necessary documents.

3. An application for recognition or enforcement may be accompanied by a document relating to the judgment, issued by a court (including an officer of the court) of the State of origin, in the form recommended and published by the Hague Conference on Private International Law.

4. If the documents referred to in this Article are not in an official language of the requested State, they shall be accompanied by a certified translation into an official language, unless the law of the requested State provides otherwise.

\section{Article 15}

Procedure

1. The procedure for recognition, declaration of enforceability or registration for enforcement, and the enforcement of the judgment, are governed by the law of the requested State unless this Convention provides otherwise. The court addressed shall act expeditiously.

2. The court of the requested State shall not refuse the recognition or enforcement of a judgment under this Convention on the ground that recognition or enforcement should be sought in another State.

[Article 16

Costs of proceedings

1. No security, bond or deposit, however described, shall be required from a party who in one Contracting State applies for enforcement of a judgment given in another Contracting State on the sole ground that such party is a foreign national or is not domiciled or resident in the State in which enforcement is sought.

2. An order for payment of costs and expenses of proceedings, made in a Contracting State against any person exempt from requirements as to security, bond, or deposit by virtue of paragraph 1 shall, on the application of the person entitled to the benefit of the order, be rendered enforceable in any other Contracting State.]

Article 17

Recognition or enforcement under national law

Subject to Article 6, this Convention does not prevent the recognition or enforcement of judgments under national law. 


\section{CHAPTER III - GENERAL CLAUSES}

Article 18

Transitional provision

This Convention shall apply to the recognition and enforcement of judgments if, at the time the proceedings were instituted in the State of origin, the Convention was in force in that State and in the requested State.

[Article 19

No legalisation

All documents forwarded or delivered under this Convention shall be exempt from legalisation or any analogous formality, including an Apostille.]

Article 20

Declarations limiting recognition and enforcement

A State may declare that its courts may refuse to recognise or enforce a judgment given by a court of another Contracting State if the parties were resident in the requested State, and the relationship of the parties and all other elements relevant to the dispute, other than the location of the court of origin, were connected only with the requested State.

Article 21

Declarations with respect to specific matters

1. Where a State has a strong interest in not applying this Convention to a specific matter, that State may declare that it will not apply the Convention to that matter. The State making such a declaration shall ensure that the declaration is no broader than necessary and that the specific matter excluded is clearly and precisely defined.

2. With regard to that matter, the Convention shall not apply -

(a) in the Contracting State that made the declaration;

(b) in other Contracting States, where recognition or enforcement of a judgment given in a Contracting State that made the declaration is sought.

[Article 22

Declarations with respect to common courts

1. A Contracting State may declare that -

(a) a court common to two or more States exercises jurisdiction over matters that come within the scope of this Convention; and

(b) such a court -

(i) has only an appellate function; or

(ii) has first instance and appellate functions.

2. Judgments of a Contracting State include -

(a) judgments given by a court referred to in paragraph 1(b)(i);

(b) judgments given by a court referred to in paragraph 1(b)(ii) if all States referred to in paragraph $1(\mathrm{a})$ are parties to this Convention.

3. If a court referred to in paragraph 1 (b)(i) serves as a common court for States some of which are Contracting States and some of which are non-Contracting States to this Convention, judgments given by such a court shall only be considered as judgments of a Contracting State if the proceedings at first instance were instituted in a Contracting State. 
4. In case of a judgment given by a court referred to in paragraph 1 (b)(ii) the reference to the State of origin in Articles 5 and 6 shall be deemed to refer to the entire territory over which that court had jurisdiction in relation to that judgment.]

Article 23

Uniform interpretation

In the interpretation of this Convention, regard shall be had to its international character and to the need to promote uniformity in its application.

Article 24

Review of operation of the Convention

The Secretary General of the Hague Conference on Private International Law shall at regular intervals make arrangements for -

(a) review of the operation of this Convention, including any declarations; and

(b) consideration of whether any amendments to this Convention are desirable.

Article 25

Non-unified legal systems

1. In relation to a Contracting State in which two or more systems of law apply in different territorial units with regard to any matter dealt with in this Convention -

(a) any reference to the law or procedure of a State shall be construed as referring, where appropriate, to the law or procedure in force in the relevant territorial unit;

(b) any reference to habitual residence in a State shall be construed as referring, where appropriate, to habitual residence in the relevant territorial unit;

(c) any reference to the court or courts of a State shall be construed as referring, where appropriate, to the court or courts in the relevant territorial unit;

(d) any reference to a connection with a State shall be construed as referring, where appropriate, to a connection with the relevant territorial unit.

2. Notwithstanding the preceding paragraph, a Contracting State with two or more territorial units in which different systems of law apply shall not be bound to apply this Convention to situations which involve solely such different territorial units.

3. A court in a territorial unit of a Contracting State with two or more territorial units in which different systems of law apply shall not be bound to recognise or enforce a judgment from another Contracting State solely because the judgment has been recognised or enforced in another territorial unit of the same Contracting State under this Convention.

4. This Article shall not apply to a Regional Economic Integration Organisation.

Article 26

Relationship with other international instruments

1. This Convention shall be interpreted so far as possible to be compatible with other treaties in force for Contracting States, whether concluded before or after this Convention. 
2. This Convention shall not affect the application by a Contracting State of a treaty that was concluded before this Convention entered into force for that Contracting State, if applying this Convention would be inconsistent with the obligations of that Contracting State to any nonContracting State. This paragraph shall also apply to treaties that revise or replace a treaty concluded before this Convention entered into force for that Contracting State, except to the extent that the revision or replacement creates new inconsistencies with this Convention.

3. This Convention shall not affect the application by a Contracting State of a treaty, whether concluded before or after this Convention, for the purposes of obtaining recognition or enforcement of a judgment given by a court of a Contracting State that is also a Party to that treaty. However, the judgment shall not be recognised or enforced to a lesser extent than under this Convention.

4. This Convention shall not affect the application by a Contracting State of a treaty which, in relation to a specific matter, governs the recognition or enforcement of judgments, even if concluded after this Convention and even if all States concerned are Parties to this Convention. This paragraph shall apply only if the Contracting State has made a declaration in respect of the treaty under this paragraph. In the case of such a declaration and to the extent that any inconsistencies exist between the above-mentioned treaty and this Convention, other Contracting States shall not be obliged to apply this Convention to a judgment which relates to that specific matter and which was rendered by a court of a Contracting State that made the declaration.

5. This Convention shall not affect the application of the rules of a Regional Economic Integration Organisation that is a Party to this Convention, whether adopted before or after this Convention as concerns the recognition or enforcement of judgments as between Member States of the Regional Economic Integration Organisation.

\section{CHAPTER IV - FINAL CLAUSES}

Article 27

Signature, ratification, acceptance, approval or accession

1. This Convention is open for signature by all States.

2. This Convention is subject to ratification, acceptance or approval by the signatory States.

3. This Convention is open for accession by all States.

4. Instruments of ratification, acceptance, approval or accession shall be deposited with the Ministry of Foreign Affairs of the Kingdom of the Netherlands, depositary of the Convention.

Article 28

Declarations with respect to non-unified legal systems

1. If a State has two or more territorial units in which different systems of law apply in relation to matters dealt with in this Convention, it may at the time of signature, ratification, acceptance, approval or accession declare that the Convention shall extend to all its territorial units or only to one or more of them and may modify this declaration by submitting another declaration at any time.

2. A declaration shall be notified to the depositary and shall state expressly the territorial units to which the Convention applies.

3. If a State makes no declaration under this Article, the Convention shall extend to all territorial units of that State. 
4. This Article shall not apply to a Regional Economic Integration Organisation.

Article 29

Regional Economic Integration Organisations

1. A Regional Economic Integration Organisation which is constituted solely by sovereign States and has competence over some or all of the matters governed by this Convention may similarly sign, accept, approve or accede to this Convention. The Regional Economic Integration Organisation shall in that case have the rights and obligations of a Contracting State, to the extent that the Organisation has competence over matters governed by this Convention.

2. The Regional Economic Integration Organisation shall, at the time of signature, acceptance, approval or accession, notify the depositary in writing of the matters governed by this Convention in respect of which competence has been transferred to that Organisation by its Member States. The Organisation shall promptly notify the depositary in writing of any changes to its competence as specified in the most recent notice given under this paragraph.

3. For the purposes of the entry into force of this Convention, any instrument deposited by a Regional Economic Integration Organisation shall not be counted unless the Regional Economic Integration Organisation declares in accordance with Article 30, paragraph 1, that its Member States will not be Parties to this Convention.

4. Any reference to a "Contracting State" or "State" in this Convention shall apply equally, where appropriate, to a Regional Economic Integration Organisation that is a Party to it.

Article 30

Accession by a Regional Economic Integration Organisation without its Member States

1. At the time of signature, acceptance, approval or accession, a Regional Economic Integration Organisation may declare that it exercises competence over all the matters governed by this Convention and that its Member States will not be Parties to this Convention but shall be bound by virtue of the signature, acceptance, approval or accession of the Organisation.

2. In the event that a declaration is made by a Regional Economic Integration Organisation in accordance with paragraph 1, any reference to a "Contracting State" or "State" in this Convention shall apply equally, where appropriate, to the Member States of the Organisation.

Article 31

Entry into force

1. This Convention shall enter into force on the first day of the month following the expiration of [three] [six] months after the deposit of the second instrument of ratification, acceptance, approval or accession referred to in Article 27.

2. Thereafter this Convention shall enter into force -

(a) for each State or Regional Economic Integration Organisation subsequently ratifying, accepting, approving or acceding to it, on the first day of the month following the expiration of [three][six] months after the deposit of its instrument of ratification, acceptance, approval or accession;

(b) for a territorial unit to which this Convention has been extended in accordance with Article 28 on the first day of the month following the expiration of [three] [six] months after the notification of the declaration referred to in that Article. 
1. Declarations referred to in Articles 20, 21, 26(4), 28 and 30 may be made upon signature, ratification, acceptance, approval or accession or at any time thereafter, and may be modified or withdrawn at any time.

2. Declarations, modifications and withdrawals shall be notified to the depositary.

3. A declaration made at the time of signature, ratification, acceptance, approval or accession shall take effect simultaneously with the entry into force of this Convention for the State concerned.

4. A declaration made at a subsequent time, and any modification or withdrawal of a declaration, shall take effect on the first day of the month following the expiration of [three] [six] months following the date on which the notification is received by the depositary.

5. A declaration made at a subsequent time, and any modification or withdrawal of a declaration, shall not apply to judgments resulting from proceedings that have already been instituted before the court of origin when the declaration takes effect.

Article 33

Denunciation

1. This Convention may be denounced by notification in writing to the depositary. The denunciation may be limited to certain territorial units of a non-unified legal system to which this Convention applies.

2. The denunciation shall take effect on the first day of the month following the expiration of twelve months after the date on which the notification is received by the depositary. Where a longer period for the denunciation to take effect is specified in the notification, the denunciation shall take effect upon the expiration of such longer period after the date on which the notification is received by the depositary.

Article 34

Notifications by the depositary

The depositary shall notify the Members of the Hague Conference on Private International Law, and other States and Regional Economic Integration Organisations which have signed, ratified, accepted, approved or acceded in accordance with Articles [...] of the following -

(a) the signatures, ratifications, acceptances, approvals and accessions referred to in Article 27;

(b) the date on which this Convention enters into force in accordance with Article 31;

(c) the notifications, declarations, modifications and withdrawals of declarations referred to in Article 32; and

(d) the denunciations referred to in Article 33. 